\title{
Evaluation of Low-Carbon Sustainable Technologies in Agriculture Sector through Grey Ordinal Priority Approach
}

\author{
Islam Shajedul ${ }^{1 \text {,* }}$ \\ ${ }^{1}$ School of Business, Nanjing University of Information Science and Technology, Nanjing, China, 210044 \\ *Corresponding author: shajedul@qq.com
}

Received 10 March 2021; Revised 4 April 2021; Accepted 20 April 2021

\begin{abstract}
The agriculture sector plays a vital role in the economy, society, and environment, the three dimensions of sustainability. The agriculture sector contributes $12 \%$ to $14 \%$ of global greenhouse gas (GHG) emissions to the atmosphere, negatively impacting climate change. Using low-carbon and sustainable agricultural technologies can help mitigate climate change and global food security issues. But selecting and prioritizing the best technologies among all alternatives has always been an issue for decision-makers because of various uncertainty related to the agricultural sector. Therefore, the current study intends to identify and prioritize the key low-carbon and sustainable agricultural technologies. The current study makes a pioneering attempt in employing the Grey Ordinal Priority Approach (OPA-G), a modern multi-attribute decision-making technique, for the evaluation of low-carbon and sustainable technologies for the agricultural sector.
\end{abstract}

Keywords: Low-carbon; agricultural technology; grey system theory; multiple criteria decision making; grey ordinal priority approach; sustainable development

\section{Introduction}

Reducing emissions from agricultural activities is a global issue getting exceeding attention these days. For minimizing the carbon emissions from the agriculture sector, the role of low carbon technologies is hard to ignore. The agriculture-related activities produce emissions that negatively affect the environment. These emissions are usually associated with livestock, burning of crop residues, using $\mathrm{N}$ fertilizer, agricultural soil, enteric fermentation, biomass burning, deforestation etc. (Khan, 2020). Studies have argued that sustainable agricultural technologies can play an essential role in achieving low carbon agriculture plans (Vinholis et al., 2021) and ensuring green food production for resource conservation (Zaman, 2020). Unlike the emissions from other energy-intensive economic sectors, the agriculture sector's greenhouse gas emissions are usually underestimated (McMahon, 2019). Agriculturerelated activity directly contributes $12 \%-14 \%$ of global greenhouse gas (GHG) emissions to the atmosphere (Beach et al., 2008; Tian et al., 2011). China, India, Brazil, and the USA are the biggest emitter of GHG from the agricultural sector. Agricultural activity in other developing countries is also growing at a fast pace (Bennetzen et al., 2016), indicating greater emissions in the future. The current study recognizes this fact and tries to highlight the issue of greenhouse gas emissions from the agriculture sector and its implications for sustainable development and food security issues. Notably, 
low-carbon and sustainable agricultural technologies can help agricultural sectors of different countries reduce emissions.

It is always difficult to select suitable technologies for the agricultural industry (Ren et al., 2017). Hence, considering sustainable criteria such as economic, social, and environmental, it has become even more difficult for the decision-makers to select the best low-carbon and sustainable technologies for the agricultural industry. However, multiple criteria decision-making (MCDM) is a popular technique to identify the best alternative among all possible alternatives based on different conflicting criteria. Thus, numerous decision-making methods have been proposed to date to solve MCDM problems. For example, Wang et al. (2018) used the Fuzzy AHP-VIKOR method to prioritize sustainable energy technology for the agricultural sector. Yu et al. (2019), Memari et al. (2019), and Li et al. (2019) applied the TOPSIS method for selecting the best suppliers for different industries. Amindoust (2018) and Ghadimi et al. (2018) used a fuzzy inference system to deal with the uncertainty in supplier selection. These studies proved the wide acceptance of MCDM methods among scholars. However, considering the variety of applications in decision-making methods, it is observed that there are many limitations in existing MCDM models (Mahmoudi et al., 2020). Javed et al. (2020) classified uncertainty in MCDM methods into five classes, as shown in Figure 1.

In light of the above discussion, the current study attempts to find a reliable solution for the decisionmakers so that they can select the best possible alternatives based on different criteria. The present study uses the Grey Ordinal Priority Approach (OPA-G), a modern multi-attribute decision-making technique, to evaluate low-carbon and sustainable agricultural technologies while dealing with most of the problems mentioned above.

The rest of the study is organized as follows. Section two describes the reviews of literature related to the role of agriculture in sustainable development goals (SDGs), finds the primary sources of emissions from the agricultural sector, and identified the critical low-carbon and sustainable agriculture technology that can play an important role in mitigating climate change and provide global food security. Grey Ordinal Priority Approach (OPA-G) model is also explained. Section three develops the Grey Ordinal priority approach (OPA-G), a modern multi-attribute decision-making model that will help evaluate low-carbon and sustainable agricultural technologies. Section four describes the result and discussion of the OPA-G model, and finally, the study will conclude with essential suggestions and implications for the countries where agriculture plays a vital role in the economy and maintaining food security.

\section{Literature Review}

\subsection{Role of Agriculture Sector in Sustainable Development}

The concept of sustainable development (SD) is relatively new, but, today it is one of the most widely discussed topics worldwide. According to the United Nations Bruntland Commission Report (1987), it is the "development that meets the needs of the present without compromising the ability of future generations to meet their own needs." The agriculture sector is a key sector contributing to sustainable development (Smith et al., 2014). According to FAO (2020.), among 17 sustainable development goals (SDGs) promoted by the United Nations, SDG1, SDG2, and SDG13 are directly linked to the Agricultural sector. To achieve sustainability in the agricultural sector, it must meet the present and future generations' needs by ensuring all the sustainability dimensions (economic, social and environmental) (FAO, 2021). But climate change poses the biggest threat to the agricultural sector; global agricultural production and food security already has been compromised due to climate change (IPCC, 2012). Growing evidence indicates that Climate change, agriculture, and global food security are closely linked to each other (Huo \& Huo., 2019; Ray et al., 2015; Hatfield et al., 2014; Wheeler \& Braun, 2013; Olesen et al., 2011). It is important to note that agricultural production also has a negative impact on the environment, e.g., various agricultural activities such as tillage, livestock, burning of crop residues, using $\mathrm{N}$ fertilizer, agricultural soil, enteric fermentation, biomass burning, deforestation etc. release a huge amount of anthropogenic greenhouse gas (GHG) to the atmosphere (Li et al., 2021; Vetter et al., 2017). They have also argued that adopting low carbon and sustainable agricultural technology can help mitigate climate change and achieve sustainable development. 


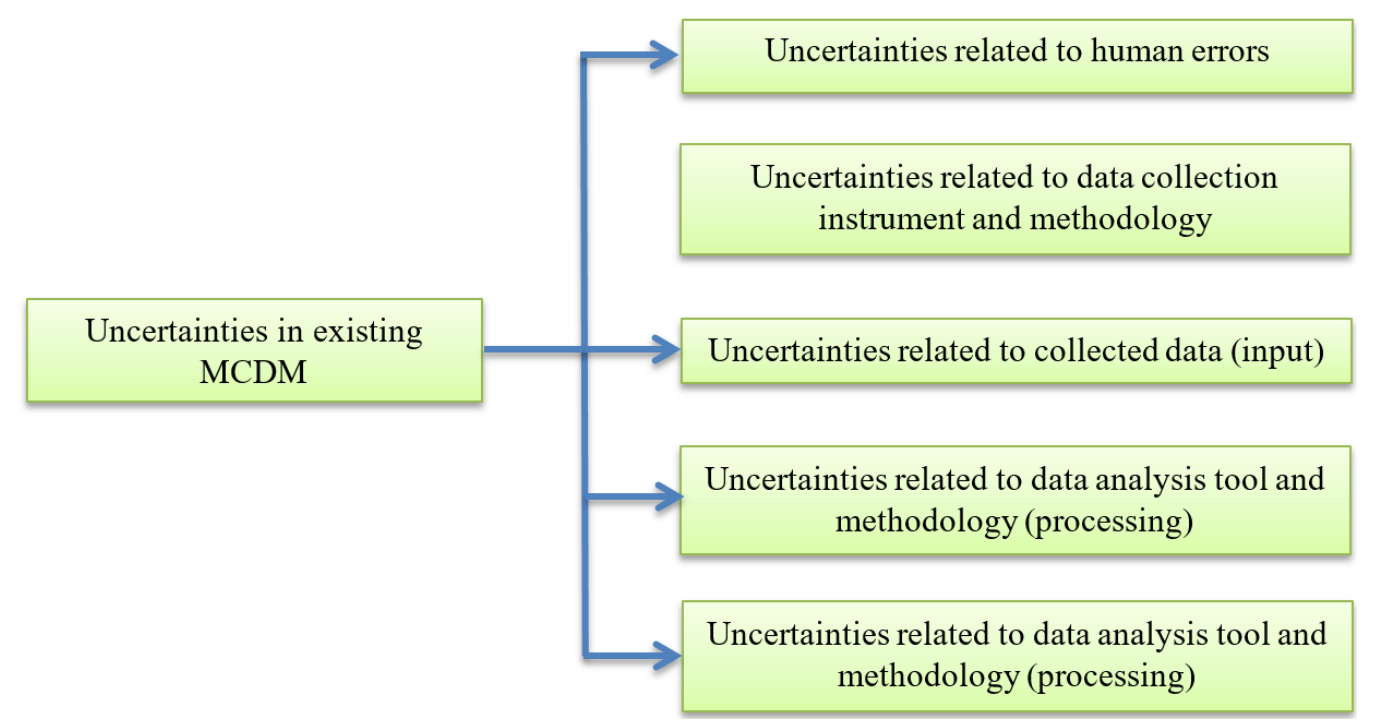

Figure 1. Five-dimensional uncertainties in MCDM methods (Source: Javed et al., 2020)

\subsection{Overview of Greenhouse Gases Emissions from Agriculture Sector}

Agricultural activities directly contribute greenhouse gas (GHG) emissions to the atmosphere (Beach et al., 2008; Tian et al., 2011). Paustian et al. (2016) highlighted that 10\% - 14\% of global GHG emissions are related to agricultural production. A study by World Resources Institute has argued that the agricultural sector is the world's second-largest GHG emitter, after the energy sector, and this trend is less likely to change in the future (Russell, 2014). Unless taking any action to mitigate climate change, GHG emissions from the agricultural sector will reach $58 \%$ by 2050 (Arcipowska et al., 2019). However, currently, GHS emissions from the agriculture sector are estimated at approximately $60 \%$ from Africa and Latin America, 30\% from Asia, and 10\% from Europe and North America (Anuga et al., 2020). Considering the last twenty years, 1996 - 2016, China, India, the USA, and Brazil were the most responsible countries for GHG emissions from the agricultural sector. $37 \%$ of global agricultural GHG emission comes from these four countries (Arcipowska et al., 2019). Similarly, agricultural GHG emissions in other regions such as Africa also rises dramatically in the last 20 years. Average annual GHG emissions from the agriculture sector increase between $2.9 \%$ to $3.1 \%$, while in China and India, it has increased by $16 \%$ and $14 \%$, respectively. Meanwhile, Australia, Argentina, and Brazil are the top three countries for agricultural emission in terms of per capita (Tongwane \& Moeletsi, 2018). Many studies have documented that the primary sources of GHG emissions from the agricultural sector are livestock, burning of crop residues, use of $\mathrm{N}$ fertilizer, enteric fermentation, biomass burning, deforestation etc. (Lybbert \& Sumner. 2012; Khan et al., 2020; EU, 2020). See Figure 2 for details. Moreover, many researchers have pointed that there is a tremendous opportunity to mitigate a substantial amount of GHG from the agriculture sector through changes in agricultural management practice in different regions around the world; China (Li et al., 2021; Huo \& Huo, 2019), India (Pathak et al., 2012), Brazil (Vinholis et al., 2021), Europe (EU, 2020), France (Meynard et al., 2018), Sub-Saharan Africa (Powlson et al., 2016), South America (De et al., 2017), these changes are closely related to lowcarbon and sustainable agriculture technologies which can help the agricultural sector to mitigate climate change by reducing GHG emission and drive towards global food security and sustainable development.

\subsection{Causes of $\mathrm{CO}_{2}$ Emissions from Agriculture Sector}

Like other industries, the agricultural sector is also responsible for producing a huge amount of carbon dioxide $\left(\mathrm{CO}_{2}\right)$. Several studies have been executed to find the leading causes of $\mathrm{CO}_{2}$ emission from the agricultural sector. Agricultural management practices, such as tillage, residues management, 


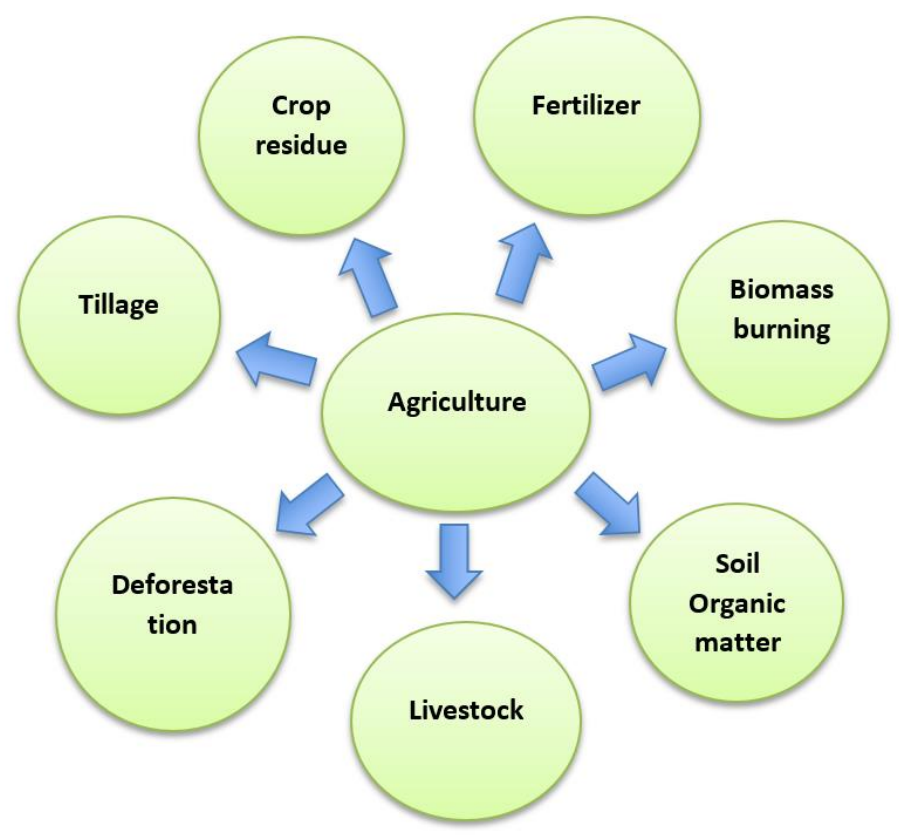

Figure 2. Primary sources of carbon emission from the agricultural sector

fertilizer management, are the key sources of $\mathrm{CO}_{2}$ fluxes from agriculture to the atmosphere (Khan et al., 2020; Sikora et al., 2020). The use of fossil fuel in different agricultural operations, manufacturing of fertilizer, and pesticides are also responsible for producing $\mathrm{CO}_{2}$ (Bhatia et al., 2012; Redman et al., 2020). Soil is the largest pool of CO2, storing about $2344 \mathrm{PgC}$ of soil organic carbon SOC (Jobbágy \& Jackson., 2000). There is considerable evidence in the literature that confirms that conventional tillage system release protected SOC by disturbance and disruption of the soil, causing the soil to release a substantial amount of $\mathrm{CO}_{2}$ into the atmosphere (Dimassi et al., 2014; Luo et al., 2010; Ussiri \& Lal, 2009; Six et al., 2004). Abdalla et al. (2016) have argued that soil management (especially tillage systems) plays a crucial role in $\mathrm{CO}_{2}$ emission from agriculture. Using a Meta-Analysis, they have observed that a no-tillage system can reduce up to $21 \%$ of $\mathrm{CO}_{2}$ emissions than the conventional tillage system, which can significantly help mitigate climate change. However, not only tillage system contributes $\mathrm{CO}_{2}$ emission to the atmosphere, but leftover material from agriculture (crop residues) also contains a high amount of $\mathrm{CO}_{2}$ (Cardoen et al., 2015). Considering ten years from 2003 to 2013, Cherubin et al. (2018) documented that the world has produced 3830 million metric tons (MT) of crop residues from agriculture. Deshavath et al. (2019) reported that in 2016 alone top four agricultural production countries - China, India, the USA, and Brazil - have burnt 181.8 MT of crop residues in open fields, contributing 15.8 MT of $\mathrm{CO}_{2}$ emission to the earth's atmosphere. It is happening not because of farmer's unawareness of the environmental impact of open burning of crop residues but because of a lack of idea and information about low-carbon and cost-effective technologies (Kumar \& Singh, 2021). Prasad et al. (2020) argued that crop residues have tremendous potential for producing renewable energy. Using the Life cycle assessment (LCA) method, they have shown that proper utilization of crop residues can play a vital role in cutting down net $\mathrm{CO} 2$ emissions and reducing the climate footprint from agriculture.

\subsection{Identification of Low-Carbon Sustainable Technologies in the Agriculture Sector}

Many studies have tried to identify and evaluate low carbon and sustainable agricultural technologies. Table 1 summarizes the literature on low carbon and sustainable agricultural technologies' evaluation. Based on the review of literature, the current study identified the following low carbon and sustainable agricultural technologies for potential evaluation: 
Table 1. Summary of literature on low carbon and sustainable agricultural technologies' evaluation

\begin{tabular}{|c|c|c|c|c|}
\hline Year & Description & $\begin{array}{l}\text { Country of } \\
\text { focus }\end{array}$ & Evaluation technique & Reference \\
\hline 2012 & $\begin{array}{l}\text { The study identified six low carbon } \\
\text { technologies }\end{array}$ & India & Scenario-based analysis & Pathak et al. (2012) \\
\hline 2016 & $\begin{array}{l}\text { The study identified Conservation } \\
\text { Agriculture as a critical sustainable } \\
\text { agricultural technology for the } \\
\text { mitigation potential of climate } \\
\text { change and food security }\end{array}$ & $\begin{array}{l}\text { Sub-Saharan } \\
\text { Africa }\end{array}$ & Meta-analysis & Powlson et al. (2016) \\
\hline 2015 & $\begin{array}{l}\text { The study identified integrated soil } \\
\text { fertility management (ISFM) as a } \\
\text { key technology for increasing food } \\
\text { security and GHG mitigation } \\
\text { potential }\end{array}$ & $\mathrm{N} / \mathrm{A}$ & $\mathrm{N} / \mathrm{A}$ & Roobroeck et al. (2015) \\
\hline 2015 & $\begin{array}{l}\text { The study identified } 6 \text { agricultural } \\
\text { technologies with great mitigation } \\
\text { potential }\end{array}$ & China & Bottom-up assessment & $\begin{array}{l}\text { Lybbert and Sumner } \\
(2012)\end{array}$ \\
\hline 2016 & $\begin{array}{l}\text { The study identified a No-tillage } \\
\text { system as a key agricultural } \\
\text { technology for reducing } \mathrm{CO}_{2} \\
\text { emissions }\end{array}$ & $\mathrm{N} / \mathrm{A}$ & Meta-analysis & Abdualla et al. (2016) \\
\hline 2017 & $\begin{array}{l}\text { The study identified six low carbon } \\
\text { technology (RDPLi, NT, ICLFS, } \\
\text { BNF, PCFF, IAW) }\end{array}$ & $\begin{array}{l}\text { South } \\
\text { America }\end{array}$ & Scenario-based analysis & De et al. (2017) \\
\hline 2017 & $\begin{array}{l}\text { This study identified } 9 \text { low carbon } \\
\text { and sustainable agricultural } \\
\text { technology }\end{array}$ & $\mathrm{N} / \mathrm{A}$ & Qualitative approach & Uppala et al. (2016) \\
\hline 2018 & $\begin{array}{l}\text { The study identified Crop } \\
\text { diversification as a key sustainable } \\
\text { agricultural technology }\end{array}$ & France & Threefold approach & Meynard et al. (2018) \\
\hline 2019 & $\begin{array}{l}\text { The study identified two sustainable } \\
\text { agricultural technology-based } \\
\text { different criteria }\end{array}$ & China & A fuzzy AHP-VIKOR & Wang et al. (2019) \\
\hline 2019 & $\begin{array}{l}\text { The study identified one sustainable } \\
\text { agricultural technology (SRI) }\end{array}$ & Mali & Qualitative approach & Mwalupaso et al. (2019) \\
\hline 2020 & $\begin{array}{l}\text { The study identified Agroforestry as } \\
\text { an important agricultural technology } \\
\text { for food security, increasing } \\
\text { resilience, and mitigating climate } \\
\text { change }\end{array}$ & $\begin{array}{l}\text { Southern } \\
\text { Malawi }\end{array}$ & $\begin{array}{l}\text { Double hurdle } \\
\text { specification with a } \\
\text { control function } \\
\text { approach }\end{array}$ & Amadu et al. (2020) \\
\hline 2020 & $\begin{array}{l}\text { The study identified five low carbon } \\
\text { technology }\end{array}$ & Africa & $\begin{array}{l}\text { Preferred Reporting } \\
\text { Items for Systematic } \\
\text { Reviews and Meta- } \\
\text { Analyses (PRISMA) } \\
\text { approach. }\end{array}$ & Anuga et al. (2020) \\
\hline 2020 & $\begin{array}{l}\text { The study identified ten low carbon } \\
\text { technologies }\end{array}$ & China & $\begin{array}{l}\text { Theory of Planned } \\
\text { Behavior }\end{array}$ & Li et al. (2020) \\
\hline 2020 & $\begin{array}{l}\text { The study identified crop rotation } \\
\text { as a sustainable agricultural } \\
\text { technology based on different } \\
\text { criteria }\end{array}$ & India & AHP-GIS & Singha et al. (2020) \\
\hline 2020 & $\begin{array}{l}\text { The study identified SWC and WH } \\
\text { as important sustainable agricultural } \\
\text { technology. }\end{array}$ & Ethiopia & Qualitative approach & Yaekob et al. (2020) \\
\hline 2020 & $\begin{array}{l}\text { The study identified ICLS and } \\
\text { ICLFS as a viable low carbon } \\
\text { technology }\end{array}$ & Brazil & $\begin{array}{l}\text { Econometric regression } \\
\text { models }\end{array}$ & Vinholis et al. (2021) \\
\hline 2021 & $\begin{array}{l}\text { The current study identifies (and } \\
\text { prioritizes, based on selected } \\
\text { criteria) nine low carbon agricultural } \\
\text { technology, e.g., ICLS, ICLFS, No- } \\
\text { tillage, CS, etc. }\end{array}$ & $\mathrm{N} / \mathrm{A}$ & $\begin{array}{l}\text { Grey Ordinal Priority } \\
\text { Approach (OPA-G) }\end{array}$ & The current study \\
\hline
\end{tabular}


2.4.1 Integrated crop-livestock systems (T1). Integrated crop-livestock systems (ICLS) are diversified agricultural production systems that can enhance food production and contribute to sustainable intensification while improving environmental quality by reducing net GHG emissions (Moraes et al., 2019). ICLS advances ecological interaction between different natural resources such as (crops, animals, and grassland) and reduces the need for chemical fertilizers and other inputs by developing organic fertilization from livestock waste (Hendrickson et al., 2008). This low-carbon and sustainable technology are very important for sustainability, increasing profitability, and economic stability (Russelle et al., 2007). However, despite economic, social, and environmental benefits, farmers' workload becomes a significant concern for this technology (Moraine et al., 2014).

2.4.2 No-tillage (T2). The no-tillage system is an agriculture technique that helps mitigate $\mathrm{CO}_{2}$ emissions from dry land by avoiding soil disturbance, reports Abdalla et al. (2016). Their study finds that conventional tillage system emits $21 \%$ more $\mathrm{CO}_{2}$ than No-tillage system. It is a popular agricultural technology worldwide because of its ability to maximize soil water infiltration, reduce soil erosion, and increase organic carbon stock (Page et al., 2019). However, Powlson et al. (2014) focused on its benefits and limitations. They suggested this low carbon agricultural technology significantly impacts soil properties, crop growth, and the environment. These technologies' key benefits are; increased rainfall infiltration, Increased soil biological activity, Increased crop yields, decreased risk of soil erosion, labor/time saved through avoiding tillage operations, reduced costs, and $\mathrm{CO}_{2}$ emission by elimination of fossil fuel use in tillage operations. However, despite many benefits, they have also argued that this technology has some limitations in the long term. For example, crop yields may remain unchanged in some situation, nitrous oxide emissions may increase, extra labor force for weed control may be needed, in wet climates planting crops may be delayed, machinery for planting crops may not be available in less developed countries, and farm income may not increase in near term.

2.4.3 Integrated crop-livestock-forest system (T3). According to Vinholis et al. (2020), an integrated croplivestock-forest system (CLFS) is an agro-ecosystem management practice that can improve the soil's biological, chemical, and physical conditions. This low carbon agricultural technique combines different farming systems such as crop-forest, crop-livestock, forest-livestock, and crop-livestock-forest (Valani et al. 2021). This technology's benefit includes increasing cycling and nutrient utilization efficiency, reducing production costs, and protecting climate change by reducing GHG emissions.

2.4.4 Conservation agriculture (T4). Conservation agriculture (CA) technology is considered a greener solution for mitigating negative impacts from the agricultural sector (Gilbert, 2012). It is a potential cropping system that can minimize the adverse effects of declining soil fertility and minimize environmental degradation (Kassam et al., 2009). This modern agricultural technique can enable farmers in different parts of the world to achieve sustainable agricultural production (Hobbs et al. 2008). Largescale farmers located in various regions such as North America, South America, Australia, New Zealand are benefiting by adopting CA technology (Kassam et al., 2009). Despite many complementariness, there are some constraints and challenges for adopting CA technology, especially in small-scale farming linked to limited resources such as land, labor, capital etc. (Valbuena et al., 2012). However, its advantages outweigh its limitations.

2.4.5 Integrated Soil Fertility Management (T5). Integrated Soil Fertility Management (ISFM) is considered a means of enhancing crop productivity and maximizing agronomic inputs' efficiency, thus contributing to sustainable intensification (Vanlauwe et al., 2015). ISFM is climate-smart agriculture (CSA) practices associated with cropping, fertilizers, organic resources, and other processes in addition to increasing agricultural production and input use efficiency. In the long run, ISFM provides productivity gains, increased resilience, and mitigation benefits (Roobroeck et al., 2015). Despite the usefulness of ISFM for food security, farmers' income and environmental protection lack of awareness and disbeliefs about ISFM become a significant concern for adopting this low-carbon and sustainable agricultural technology (Lambrecht et al. 2016).

2.4.6 Agroforestry (T6). The concept of agroforestry is an association of trees with crops or livestock on the same land that embraces a broad range of systems under different management schemes (Martin 


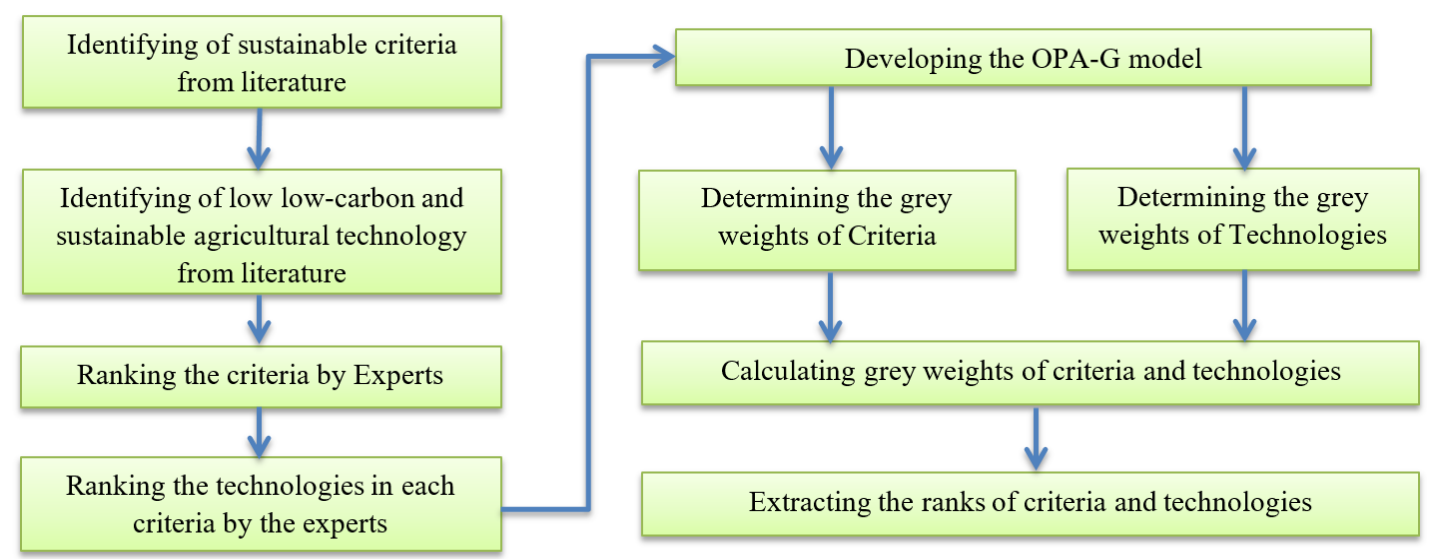

Figure 3. The framework of the study

et al., 2019), which can provide many benefits, including increase crop yields, reduce soil erosion, conserving biodiversity and increasing soil fertility (Nair et al. 2010; 2009). De Stefano and Jacobson (2018) argued that agroforestry could be a viable opportunity to tackle the climate change issues, reducing $\mathrm{CO}_{2}$ emissions from the agricultural sector. Considering all these benefits, Waldron et al. (2017) argued that agroforestry could help to increase global food security and, in the meantime, can help to achieve SDGs.

2.4.7 Carbon sequestration (T7). Carbon sequestration is the process of balancing carbon dioxide into an atmospheric $\mathrm{C}$ pool. Carbon sequestering in the agricultural sector requires a change in agricultural management practices such as pesticide use, irrigation, and machinery (West \& Marland, 2002). This technology has a considerable potential to reduce $\mathrm{CO}_{2}$ emissions from the agriculture sector and fossil fuel emissions (Schlesinge, 1999). This process gains enormous attention as an alternate way to help stem the rate of greenhouse gas growth and associated changes in our climate. Scientist prioritizes carbon sequestration as the primary goal with ancillary improvements in water management, soil erosion, and food security.

2.4.8 Crop diversification (T8). The agricultural sector is the most sensitive to the climate change issue. Studies have documented a direct link to climate change and agricultural production, more likely negative impacts than positive (Li et al., 2021; Huo \& Huo, 2019; Birthal \& Hazrana, 2019). Crop diversification has a great potentiality to increase the sustainability of arable farming systems that minimize the inputs of (irrigation water, fertilizers, pesticides) expanding the heterogeneity of habitat mosaics, or reducing yield gap associated with too frequent returns of the same species (Meynard et al., 2018). Birthal and Hazrana (2019) have found that crop diversification has many benefits in the long run. On the other hand, Magrini et al. (2016) and Lithourgidis et al. (2011) argued that historically established to support large-scale specialization, selection of appropriate crops, and short-term maximization of profits with chemical inputs are the main barriers to the adaption of this technology.

2.4.9 Soil and water conservation (T9). Soil and water conservation (SWC) is a sustainable agriculture management system that reduces soil erosion, increases agricultural production yield, and grows organic carbon stock (Mekonnen, 2020; Adimassu et al., 2017). However, different scholars have shown that the impact of SWC technology has inconsistent results on crop yield and economic profitability in the short-run (Kato et al., 2011; Kassie et al., 2011). As a result, farmer's adaption rate to this technology is meagre. Asfaw et al. (2017) pointed out that inadequate information, poor skills, and inadequate transportation and communication are responsible for this technology's low adaption, especially in developing countries. 


\subsection{Grey Ordinal Priority Approach}

2.5.1 Grey system theory. Deng Julong introduced the Grey System Theory in 1982 (Ju-Long, 1982) where a white-grey-black spectrum is used to explain the uncertainty of a system (Hao et al., 2006). Grey System Theory has a wide range of popularity among researchers from different fields because of its applicability to solve real-world situations where incomplete information and uncertainty exist. The key areas of Grey System Theory include grey relational analysis, grey generating space, grey forecasting, grey decision making, grey control, and grey mathematics. Grey System Theory has seen application in numerous fields, including agriculture (Tan et al., 2014), supplier selection (Mahmoudi et al., 2021a), economic growth analysis (Huang et al., 2020), health care management (Aydemir \& Sahin, 2019; Javed and Liu., 2018), sustainable development (Ikram et al., 2021; Abid et al., 2021), environment (Hao et al., 2006), electromagnetic data processing (Jiang et al., 2017), traffic flow prediction (Xiao et al., 2020), energy and emissions (Chen et al., 2021; Zhu et al., 2019), project management (Sheikh et al., 2019; Javed \& Liu, 2019), machine learning (Xie et al., 2021; Ma, 2019), among others. It can be seen that the application of Grey System Theory is widespread and multi-disciplinary. Some researchers even argued its superiority over other methods such as fuzzy set theory, considering the ability and flexibility of dealing with ambiguity and uncertainty, independence over membership function, and ability to handle a small sample size (Chithambaranathan et al., 2015; Ng and Deng, 1995). Grey Ordinal Priority Approach is a new multi-criteria decision-making technique that fuses the advantages of grey system theory with the Ordinal Priority Approach (OPA) and is discussed in the subsequent section.

2.5.2 Grey Ordinal Priority Approach. The ordinal priority approach (OPA) is an emerging multicriteria decision-making (MCDM) technique developed by Ataie et al. (2020) and has recently seen some extensions. They argued that this model has a strong capability of supporting both single and group decision-making. Also, it can calculate the weights for different experts, criteria, and alternatives simultaneously, while most other MCDM models only can produce a ranking of alternatives based on the expert's opinion. The recent literature has demonstrated the OPA's effectiveness with interesting results. For example, Mahmoudi et al. (2020a) showed the suitability of the OPA-based framework for problems involving big data. Mahmoudi et al. (2021b) proposed the Fuzzy Ordinal Priority Approach to solve the decision-making problems through linguistic information.

Grey Ordinal Priority Approach (OPA-G) is another important member of the OPA family and was proposed by Mahmoudi et al. (2021a). They demonstrated its effectiveness in solving sustainable supplier selection problems. They have shown that OPA-G can work without any linguistic variable or pairwise comparison-based data and have a high capability of dealing with greyness/uncertainty. While considering the ordinal priorities, the OPA-G model can provide the weights for experts, criteria, and alternatives. Table 2 shows the explanation of sets, indexes, variables, and the parameters of the OPAG model (Mahmoudi et al., 2021a).

Table 2. Sets, indexes, variables, and parameters of the OPA-G model

\begin{tabular}{|l|l|}
\hline \multicolumn{2}{|l|}{ sets } \\
\hline$I$ & Set of experts $\forall i \in I$ \\
\hline$J$ & Set of criteria $\forall j \in J$ \\
\hline$K$ & Set of alternatives $\forall k \in K$ \\
\hline \multicolumn{1}{l|}{ Indexes } & \\
\hline$i$ & Index of the experts $(1, \ldots, p)$ \\
\hline$j$ & Index of preference of the criteria $(1, \ldots, n)$ \\
\hline$k$ & Index of the alternatives $(1, \ldots, m)$ \\
\hline Variables & \\
\hline$\otimes Z$ & Grey objective function \\
\hline$\otimes W_{i j}{ }^{r}$ & Grey weight (importance) of $k^{\text {th }}$ alternative based on $j^{\text {th }}$ criterion by $i^{\text {th }}$ expert at $r^{\text {th }}$ rank \\
\hline $\boldsymbol{P a r a m e t e r s}$ \\
\hline$\otimes i$ & Grey rank of the expert $i$ \\
\hline$\otimes j$ & Grey rank of the criterion $j$ \\
\hline$\otimes r$ & Grey rank of the alternative $k$ \\
\hline
\end{tabular}


Table 3. The demographic profile of the respondents

\begin{tabular}{|l|l|}
\hline Gender & Male $(70 \%)$ \\
& Female $(30 \%)$ \\
\hline Age & More than 50 years old $(20 \%)$ \\
& $41-50$ years old $(30 \%)$ \\
& $31-40$ years old $(20 \%)$ \\
& $21-30$ years old $(30 \%)$ \\
\hline Industry & Agriculture, Forestry and Other Land Use $(80 \%)$ \\
& Other $(20 \%)$ \\
\hline Position/post & Top level manager $(40 \%)$ \\
& Middle level manager $(40 \%)$ \\
\hline Work Experience & Junior level manager $(20 \%)$ \\
& More than 12 years $(40 \%)$ \\
& $9-12$ years $(20 \%)$ \\
& $7-9$ years $(10 \%)$ years \\
& $4-6$ years $(20 \%)$ \\
\hline Organization type & $1-3$ years $(10 \%)$ \\
\hline Total sample & Public $(50 \%)$ \\
\hline
\end{tabular}

Understanding of some definitions is mandatory before the computational steps of the OPA-G are discussed. These definitions are defined below and are adapted from Mahmoudi et al. (2020).

Definition I: Grey number $\otimes A$ is described as follows:

$$
\otimes \mathrm{A}=[\underline{A}, \bar{A}], \quad \underline{A}<\bar{A}
$$

where, $\underline{A}$ is the lower limit and $\bar{A}$ is the upper limit of the grey number $\otimes A$. Here, it should be noted that a grey number should not be confused with interval. Unlike an interval, a grey number is a crisp number, and its interval merely represents greyness in the exact location of this crisp number.

Definition II: Assume that $A$ is a crisp number. Therefore, $\otimes A$ has a grey $\operatorname{rank}[\operatorname{Rank}(\mathrm{A})-0.5, \operatorname{Rank}(\mathrm{A})$ $+0.5]$. Equation (2) should be utilized to convert crisp rank $n$ to grey rank $n$.

$$
\text { Rank } \otimes n[n-0.5, n+0.5]
$$

Definition III: Assume that the expert(s) is not confident about in a choice of two ranks $x$ and $y$ for a criterion or an alternative while $x<y$. Then, Eq. (3) should be utilized for the grey rank:

$$
\operatorname{Rank}(\otimes x, \otimes y)=[\operatorname{Rank}(x)-0.5, \operatorname{Rank}(y)+0.5]
$$

The relevant computational steps of the OPA-G model are as follows (see Figure 3):

Step 1: First, the decision-makers need to determine the necessary criteria.

Step 2: The decision-makers must identify and select the relevant experts.

Step 3: The experts should give ranking to different criteria. If experts also doubt about the exact priority level for different criteria, they can utilize Definitions II and III.

Step 4: Determining the ranking for available alternatives in each criterion. In this step, experts still can use Definitions II and III to converts crisp rank into grey rank.

Step 5: After collecting all the data needed in Step 1 to Step 4 the OPA-G model should be solved using Eq. (4)

$\operatorname{Max} \otimes Z$

S.t. $(\forall i, j, k$ and $r)$ : 
$\otimes Z \leq \otimes i\left(\otimes j\left(r\left(\otimes W_{i j k}^{r}-\otimes W_{i j k}^{r+1}\right)\right)\right)$

$\otimes Z \leq \otimes i \otimes j \otimes m \otimes W_{i j k}{ }^{m}$

$\sum_{i=1}^{p} \sum_{j=1}^{n} \sum_{k=1}^{m} \otimes W_{i j k}=[0.8,1.2]$

$\otimes W_{i j k} \geq 0$

where, $\otimes Z$ is unrestricted in sign.

To obtain the individual weights of criteria and alternatives, Eqs. (5) and (6) should be employed respectively.

$$
\begin{aligned}
& W_{j}=\sum_{i=1}^{p} \sum_{j=1}^{n} W_{i j k} \quad \forall j \\
& W_{k}=\sum_{i=1}^{p} \sum_{j=1}^{n} W_{i j k} \quad \forall k
\end{aligned}
$$

Step 6: After getting all the weights of experts, criteria, and alternatives, the grey possibility degree should be calculated by the following matrix to extract the ranking of alternatives.

$$
G P_{i j}=\left[\begin{array}{cc}
P\left(W_{1} \leq W_{1}\right) & P\left(W_{1} \leq W_{2}\right) \ldots . P\left(W_{1} \leq W_{k}\right) \\
P\left(W_{2} \leq W_{1}\right) & P\left(W_{2} \leq W_{2}\right) \ldots . P\left(W_{2} \leq W_{k}\right) \\
\cdot \\
\cdot \\
P\left(W_{k} \leq W_{1}\right) & P\left(W_{k} \leq W_{2}\right) \ldots . P\left(W_{k} \leq W_{k}\right)
\end{array}\right]
$$

Finally, the following matrix results

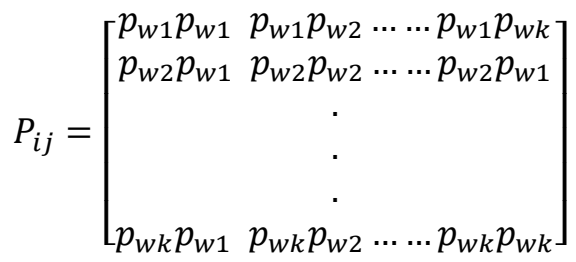

By summing up all the horizontal component of $P_{i j}$ we can get the ranking for an individual alternative. The highest value will represent the best alternative for selection.

\section{Research Methodology}

\subsection{Data Collection and Analysis}

Data were collected from a designed survey where experts were selected in a random process from 10 different countries and fields. Following the sustainability approach, we identified three different criteria (Economic, Social, and Environmental) to evaluate low carbon and sustainable agricultural technologies. Then expert opinions were sought to prioritize those criteria on a 1-3 point scale where 1 represents high priority 3 represents low priority. Table 4 shows the opinion of experts regarding the evaluation of different criteria. Based on those criteria, experts were then asked to evaluate all the available alternatives/technologies on the same processes. Demographic information of the experts is available in Table 3. The data collected from them is available in Tables 5, 6, and 7. Microsoft Excel 
was utilized for making tables and performing calculations, Google forms were utilized for preparing the questionnaire and then data collection. Lingo 9.0 software was utilized for building the OPA-G model and its execution.

\subsection{The model}

Because of the limited space, the model for one expert and three criteria is developed and shown below to introduce the readers to the model structure. In the current study, ten experts and nine criteria were involved, and the complete model was very lengthy, and thus is shown in the Appendix available at zeonodo (i.e., Shajedul, 2021). The key is islamislam.

$$
\operatorname{Max}=\frac{1}{2} * \bar{Z}+\frac{1}{2} * \underline{Z}
$$

S.t.

!Expert 1 !Criteria 1

$$
\begin{aligned}
& 1.5 * 1.5 * 1.5 *\left(\underline{W}_{11} T_{1}-\underline{W}_{11} T_{2}\right) \geq \bar{Z} \\
& 0.5 * 0.5 * 0.5 *\left(\bar{W}_{11} T_{1}-\bar{W}_{11} T_{2}\right) \geq \underline{Z} \\
& 1.5 * 1.5 * 1.5 *\left(\underline{W}_{11} T_{2}-\underline{W}_{11} T_{4}\right) \geq \bar{Z} \\
& 0.5 * 0.5 * 0.5 *\left(\bar{W}_{11} T_{2}-\bar{W}_{11} T_{4}\right) \geq \underline{Z} \\
& 1.5 * 1.5 * 1.5 *\left(\underline{W}_{11} T_{4}-\underline{W}_{11} T_{5}\right) \geq \bar{Z} \\
& 0.5 * 0.5 * 0.5 *\left(\bar{W}_{11} T_{4}-\bar{W}_{11} T_{5}\right) \geq \underline{Z} \\
& 1.5 * 1.5 * 1.5 *\left(\underline{W}_{11} T_{5}-\underline{W}_{11} T_{8}\right) \geq \bar{Z} \\
& 0.5 * 0.5 * 0.5 *\left(\bar{W}_{11} T_{5}-\bar{W}_{11} T_{8}\right) \geq \underline{Z} \\
& 1.5 * 1.5 * 1.5 *\left(\underline{W}_{11} T_{8}-\underline{W}_{11} T_{9}\right) \geq \bar{Z} \\
& 0.5 * 0.5 * 0.5 *\left(\bar{W}_{11} T_{8}-\bar{W}_{11} T_{9}\right) \geq \underline{Z} \\
& 1.5 * 1.5 * 1.5 *\left(\underline{W}_{11} T_{9}-\underline{W}_{11} T_{3}\right) \geq \bar{Z} \\
& 0.5 * 0.5 * 0.5\left(\bar{W}_{11} T_{9}-\bar{W}_{11} T_{3}\right) \geq \underline{Z} \\
& 1.5 * 1.5 * 2.5\left(\underline{W}_{11} T_{3}-\underline{W}_{11} T_{7}\right) \geq \bar{Z} \\
& 0.5 * 0.5 * 1.5\left(\bar{W}_{11} T_{3}-\bar{W}_{11} T_{7}\right) \geq \underline{Z} \\
& 1.5 * 1.5 * 2.5\left(\underline{W}_{11} T_{7}-\underline{W}_{11} T_{6}\right) \geq \bar{Z} \\
& 0.5 * 0.5 * 1.5\left(\bar{W}_{11} T_{7}-\bar{W}_{11} T_{6}\right) \geq \underline{Z} \\
& 1.5 * 1.5 * 3.5 *\left(\underline{W}_{11} T_{6}\right) \geq \bar{Z} ; \\
& 0.5 * 0.5 * 2.5 *\left(\bar{W}_{11} T_{6}\right) \geq \underline{Z} \\
& 0.51
\end{aligned}
$$

!Expert 1 !Criteria 2

$$
\begin{aligned}
& 1.5 * 2.5 * 1.5 *\left(\underline{W}_{12} T_{2}-\underline{W}_{12} T_{4}\right) \geq \bar{Z} ; \\
& 0.5 * 1.5 * 0.5 *\left(\bar{W}_{12} T_{2}-\bar{W}_{12} T_{4}\right) \geq \underline{Z} ;
\end{aligned}
$$




$$
\begin{aligned}
& 1.5 * 2.5 * 1.5 *\left(\underline{W}_{12} T_{4}-\underline{W}_{12} T_{7}\right) \geq \bar{Z} \\
& 0.5 * 1.5 * 0.5 *\left(\bar{W}_{12} T_{4}-\bar{W}_{12} T_{7}\right) \geq \underline{Z} \\
& 1.5 * 2.5 * 1.5 *\left(\underline{W}_{12} T_{7}-\underline{W}_{12} T_{9}\right) \geq \overline{Z ;} \\
& 0.5 * 1.5 * 0.5 *\left(\bar{W}_{12} T_{7}-\bar{W}_{12} T_{9}\right) \geq \underline{Z ;} \\
& 1.5 * 2.5 * 1.5 *\left(\underline{W}_{12} T_{9}-\underline{W}_{12} T_{3}\right) \geq \overline{Z ;} \\
& 0.5 * 1.5 * 0.5 *\left(\bar{W}_{12} T_{9}-\bar{W}_{12} T_{3}\right) \geq \underline{Z} \\
& 1.5 * 1.5 * 1.5 *\left(\underline{W}_{12} T_{3}-\underline{W}_{12} T_{5}\right) \geq \bar{Z} \\
& 0.5 * 0.5 * 0.5 *\left(\bar{W}_{12} T_{3}-\bar{W}_{12} T_{5}\right) \geq \underline{Z ;} \\
& 1.5 * 2.5 * 2.5 *\left(\underline{W}_{12} T_{5}-\underline{W}_{12} T_{6}\right) \geq \bar{Z} ; \\
& 0.5 * 1.5 * 1.5 *\left(\bar{W}_{12} T_{5}-\bar{W}_{12} T_{6}\right) \geq \underline{Z ;} \\
& 1.5 * 2.5 * 2.5 *\left(\underline{W}_{12} T_{6}-\underline{W}_{12} T_{8}\right) \geq \overline{Z ;} \\
& 0.5 * 1.5 * 1.5 *\left(\bar{W}_{12} T_{6}-\bar{W}_{12} T_{8}\right) \geq \underline{Z} ; \\
& 1.5 * 2.5 * 2.5 *\left(\underline{W}_{12} T_{8}-\underline{W}_{12} T_{8}\right) \geq \bar{Z} ; \\
& 0.5 * 1.5 * 1.5 *\left(\bar{W}_{12} T_{8}-\bar{W}_{12} T_{8}\right) \geq \underline{Z ;} \\
& 1.5 * 2.5 * 3.5 *\left(\underline{W}_{12} T_{8}\right) \geq \bar{Z} ; \\
& 0.5 * 1.5 * 2.5 *\left(\bar{W}_{12} T_{8}\right) \geq \underline{Z ;}
\end{aligned}
$$

!Expert 1 !Criteria 3

$$
\begin{aligned}
& 1.5 * 1.5 * 1.5 *\left(\underline{W}_{13} T_{2}-\underline{W}_{13} T_{3}\right) \geq \overline{Z ;} \\
& 0.5 * 0.5 * 0.5 *\left(\bar{W}_{13} T_{2}-\bar{W}_{13} T_{3}\right) \geq \underline{Z} \\
& 1.5 * 1.5 * 1.5 *\left(\underline{W}_{13} T_{3}-\underline{W}_{13} T_{4}\right) \geq \overline{Z ;} \\
& 0.5 * 0.5 * 0.5 *\left(\bar{W}_{13} T_{3}-\bar{W}_{13} T_{4}\right) \geq \underline{Z} \\
& 1.5 * 1.5 * 1.5 *\left(\underline{W}_{13} T_{4}-\underline{W}_{13} T_{6}\right) \geq \bar{Z} \\
& 0.5 * 0.5 * 0.5 *\left(\bar{W}_{13} T_{4}-\bar{W}_{13} T_{6}\right) \geq \underline{Z} \\
& 1.5 * 1.5 * 1.5 *\left(\underline{W}_{13} T_{6}-\underline{W}_{13} T_{7}\right) \geq \bar{Z} ; \\
& 0.5 * 0.5 * 0.5 *\left(\bar{W}_{13} T_{6}-\bar{W}_{13} T_{7}\right) \geq \underline{Z} \\
& 1.5 * 1.5 * 1.5 *\left(\underline{W}_{13} T_{7}-\underline{W}_{13} T_{9}\right) \geq \bar{Z} ; \\
& 0.5 * 0.5 * 0.5 *\left(\bar{W}_{13} T_{7}-\bar{W}_{13} T_{9}\right) \geq \underline{Z} ; \\
& 1.5 * 1.5 * 1.5 *\left(\underline{W}_{13} T_{9}-\underline{W}_{13} T_{5}\right) \geq \bar{Z} ; \\
& 0.5 * 0.5 * 0.5 *\left(\bar{W}_{13} T_{9}-\bar{W}_{13} T_{5}\right) \geq \underline{Z ;}
\end{aligned}
$$




$$
\begin{aligned}
& 1.5 * 1.5 * 2.5 *\left(\underline{W_{13}} T_{5}-\underline{W_{13}} T_{8}\right) \geq \bar{Z} \\
& 0.5 * 0.5 * 1.5 *\left(\bar{W}_{13} T_{5}-\bar{W}_{13} T_{8}\right) \geq \underline{Z} \text {; } \\
& 1.5 * 1.5 * 2.5 *\left(\underline{W}_{13} T_{8}-\underline{W}_{13} T_{1}\right) \geq \bar{Z} ; \\
& 0.5 * 0.5 * 1.5 *\left(\bar{W}_{13} T_{8}-\bar{W}_{13} T_{1}\right) \geq \underline{Z} ; \\
& 1.5 * 1.5 * 3.5 *\left(\underline{W}_{13} T_{1}\right) \geq \overline{Z ;} \\
& 0.5 * 0.5 * 2.5 *\left(\bar{W}_{13} T_{1}\right) \geq \underline{Z} ; \\
& \bar{W}_{11} T_{1}+\bar{W}_{11} T_{2}+\bar{W}_{11} T_{3}+\bar{W}_{11} T_{4}+\bar{W}_{11} T_{5}+\bar{W}_{11} T_{6}+\bar{W}_{11} T_{7}+\bar{W}_{11} T_{8}+\bar{W}_{11} T_{9}+\bar{W}_{12} T_{1} \\
& +\bar{W}_{12} T_{2}+\bar{W}_{12} T_{3}+\bar{W}_{12} T_{4}+\bar{W}_{12} T_{5}+\bar{W}_{12} T_{6}+\bar{W}_{12} T_{7}+\bar{W}_{12} T_{8}+\bar{W}_{12} T_{9} \\
& +\bar{W}_{13} T_{1}+\bar{W}_{13} T_{2}+\bar{W}_{13} T_{3}+\bar{W}_{13} T_{4}+\bar{W}_{13} T_{5}+\bar{W}_{13} T_{6}+\bar{W}_{13} T_{7}+\bar{W}_{13} T_{8} \\
& +\bar{W}_{13} T_{9}=1.2 \\
& \underline{W_{11}} T_{1}+\underline{W_{11}} T_{2}+\underline{W_{11}} T_{3}+\underline{W}_{11} T_{4}+\underline{W}_{11} T_{5}+\underline{W}_{11} T_{6}+\underline{W_{11}} T_{7}+\underline{W_{11}} T_{8}+\underline{W}_{11} T_{9}+\underline{W}_{12} T_{1} \\
& +\underline{W}_{12} T_{2}+\underline{W}_{12} T_{3}+\underline{W}_{12} T_{4}+\underline{W}_{12} T_{5}+\underline{W}_{12} T_{6}+\underline{W}_{12} T_{7}+\underline{W}_{12} T_{8}+\underline{W}_{12} T_{9} \\
& +\underline{W}_{13} T_{1}+\underline{W}_{13} T_{2}+\underline{W_{13}} T_{3}+\underline{W_{13}} T_{4}+\underline{W}_{13} T_{5}+\underline{W_{13}} T_{6}+\underline{W_{13}} T_{7}+\underline{W_{13}} T_{8} \\
& +\underline{W_{13}} T_{9}=0.8 \\
& \bar{Z} \geq \underline{Z} \\
& \bar{W}_{11} T_{1} \geq \underline{W}_{11} T_{1} ; \bar{W}_{11} T_{2} \geq \underline{W}_{11} T_{2} ; \bar{W}_{11} T_{3} \geq \underline{W}_{11} T_{3} ; \bar{W}_{11} T_{4} \geq \underline{W_{11}} T_{4} ; \bar{W}_{11} T_{5} \geq \underline{W}_{11} T_{5} ; \bar{W}_{11} T_{6} \\
& \geq \underline{W}_{11} T_{6} ; \bar{W}_{11} T_{7} \geq \underline{W}_{11} T_{7} ; \bar{W}_{11} T_{8} \geq \underline{W}_{11} T_{8} ; \bar{W}_{11} T_{9} \geq \underline{W}_{11} T_{9} ; \bar{W}_{12} T_{1} \\
& \geq \underline{W}_{12} T_{1} ; \bar{W}_{12} T_{2} \geq \underline{W}_{12} T_{2} ; \bar{W}_{12} T_{3} \geq \underline{W}_{12} T_{3} ; \bar{W}_{12} T_{4} \geq \underline{W}_{12} T_{4} ; \bar{W}_{12} T_{5} \\
& \geq \underline{W}_{12} T_{5} ; \bar{W}_{12} T_{6} \geq \underline{W}_{12} T_{6} ; \bar{W}_{12} T_{7} \geq \underline{W}_{12} T_{7} ; \bar{W}_{12} T_{8} \geq \underline{W}_{12} T_{8} ; \bar{W}_{12} T_{9} \\
& \geq \underline{W_{12}} T_{9} ; \bar{W}_{13} T_{1} \geq \underline{W}_{13} T_{1} ; \bar{W}_{13} T_{2} \geq \underline{W}_{13} T_{2} ; \bar{W}_{13} T_{3} \geq \underline{W}_{13} T_{3} ; \bar{W}_{13} T_{4}
\end{aligned}
$$

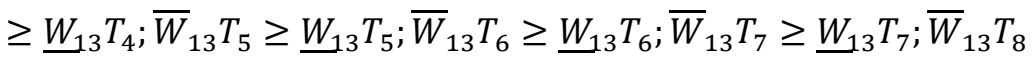

$$
\begin{aligned}
& \geq \underline{W_{13}} T_{8} ; \bar{W}_{13} T_{9} \geq \underline{W_{13}} T_{9} ; \\
& \underline{W_{11}} T_{1}, \underline{W_{11}} T_{2}, \underline{W_{11}} T_{3}, \underline{W_{11}} T_{4}, \underline{W_{11}} T_{5}, \underline{W}_{11} T_{6}, \underline{W_{11}} T_{7}, \underline{W_{11}} T_{8} \\
& \underline{W_{11}} T_{9}, \underline{W_{12}} T_{1}, \underline{W_{12}} T_{2}, \underline{W_{12}} T_{3}, \underline{W_{12}} T_{4}, \underline{W_{12}} T_{5}, \underline{W_{12}} T_{6}, \underline{W_{12}} T_{7} \text {, } \\
& \underline{W_{12}} T_{8}, \underline{W_{12}} T_{9}, \underline{W_{13}} T_{1}, \underline{W_{13}} T_{2}, \underline{W_{13}} T_{3}, \underline{W_{13}} T_{4}, \underline{W_{13}} T_{5}, \underline{W_{13}} T_{6}, \\
& \underline{W_{13}} T_{7}, \underline{W_{13}} T_{8}, \underline{W_{13}} T_{9} \geq 0 .
\end{aligned}
$$

\section{Data and results}

The study involves three sustainability criteria, ten experts, and nine different alternatives that can be seen from Tables 4 to 7. It is important to note that the study considered all the experts to be of equally important. However, it is worth noting that the OPA-G can calculate the experts' weights as well, if needed. After solving the model, weights and ranking for criteria and alternatives are shown in Tables 8 and 9. To obtain the weights of criteria and alternatives, Eqs. (5) and (6) are employed. Afterward, to extract the ranking for criteria and alternatives matrix $P_{j i}$ has been estimated using Eq. (8). 
Table 4. Experts' opinions regarding importance of different criteria

\begin{tabular}{|c|c|c|c|c|}
\hline Experts & Rank Type & Economic criterion (C1) & Social criterion (C3) & Environmental criterion (C2) \\
\hline \multirow[t]{2}{*}{ E1 } & Crispy Rank (CR) & 1 & 2 & 1 \\
\hline & Grey Rank (GR) & {$[0.5,1.5]$} & {$[1.5,2.5]$} & {$[0.5,1.5]$} \\
\hline \multirow[t]{2}{*}{ E2 } & Crispy Rank (CR) & 1 & 2 & 1 \\
\hline & Grey Rank (GR) & {$[0.5,1.5]$} & {$[1.5,2.5]$} & {$[0.5,1.5]$} \\
\hline \multirow[t]{2}{*}{ E3 } & Crispy Rank (CR) & 1 & 3 & 2 \\
\hline & Grey Rank (GR) & {$[0.5,1.5]$} & {$[2.5,3.5]$} & {$[1.5,2.5]$} \\
\hline \multirow[t]{2}{*}{$\mathrm{E} 4$} & Crispy Rank (CR) & 1 & 2 & 1 \\
\hline & Grey Rank (GR) & {$[0.5,1.5]$} & {$[1.5,2.5]$} & {$[0.5,1.5]$} \\
\hline \multirow[t]{2}{*}{ E5 } & Crispy Rank (CR) & 1 & 3 & 2 \\
\hline & Grey Rank (GR) & {$[0.5,1.5]$} & {$[2.5,3.5]$} & {$[1.5,2.5]$} \\
\hline \multirow[t]{2}{*}{ E6 } & Crispy Rank (CR) & 1 & 1 & 1 \\
\hline & Grey Rank (GR) & {$[0.5,1.5]$} & {$[0.5,1.5]$} & {$[0.5,1.5]$} \\
\hline \multirow[t]{2}{*}{ E7 } & Crispy Rank (CR) & 2 & 2 & 1 \\
\hline & Grey Rank (GR) & {$[1.5,2.5]$} & {$[1.5,2.5]$} & {$[0.5,1.5]$} \\
\hline \multirow[t]{2}{*}{ E8 } & Crispy Rank (CR) & 1 & 2 & 1 \\
\hline & Grey Rank (GR) & {$[0.5,1.5]$} & {$[1.5,2.5]$} & {$[0.5,1.5]$} \\
\hline \multirow[t]{2}{*}{ E9 } & Crispy Rank (CR) & 2 & 3 & 1 \\
\hline & Grey Rank (GR) & {$[1.5,2.5]$} & {$[2.5,3.5]$} & {$[0.5,1.5]$} \\
\hline \multirow[t]{2}{*}{ E10 } & Crispy Rank (CR) & 2 & 3 & 1 \\
\hline & Grey Rank (GR) & {$[1.5,2.5]$} & {$[2.5,3.5]$} & {$[0.5,1.5]$} \\
\hline
\end{tabular}

Table 5. Opinion of experts for the technologies against Economic criteria

\begin{tabular}{|c|c|c|c|c|c|c|c|c|c|c|}
\hline Experts & $\begin{array}{c}\text { Rank } \\
\text { Type }\end{array}$ & T1 & T2 & T3 & T4 & T5 & T6 & $T 7$ & $T 8$ & T9 \\
\hline \multirow{2}{*}{ E1 } & CR & 1 & 1 & 2 & 1 & 1 & 3 & 2 & 1 & 1 \\
\cline { 2 - 12 } & GR & {$[0.5,1.5]$} & {$[0.5,1.5]$} & {$[1.5,2.5]$} & {$[0.5,1.5]$} & {$[0.5,1.5]$} & {$[2.5,3.5]$} & {$[1.5,2.5]$} & {$[0.5,1.5]$} & {$[0.5,1.5]$} \\
\hline \multirow{2}{*}{ E2 } & CR & 1 & 2 & 4 & 2 & 4 & 5 & 1 & 3 & 2 \\
\cline { 2 - 13 } & GR & {$[0.5,1.5]$} & {$[1.5,2.5]$} & {$[3.5,4.5]$} & {$[1.5,2.5]$} & {$[3.5,4.5]$} & {$[4.5,5.5]$} & {$[0.5,1.5]$} & {$[2.5,3.5]$} & {$[1.5,2.5]$} \\
\hline \multirow{2}{*}{ E3 } & CR & 1 & 5 & 2 & 5 & 2 & 3 & 4 & 1 & 4 \\
\cline { 2 - 13 } & GR & {$[0.5,1.5]$} & {$[4.5,5.5]$} & {$[1.5,2.5]$} & {$[4.5,5.5]$} & {$[1.5,2.5]$} & {$[2.5,3.5]$} & {$[3.5,4.5]$} & {$[0.5,1.5]$} & {$[3.5,4.5]$} \\
\hline \multirow{2}{*}{ E4 } & CR & 1 & 5 & 2 & 3 & 5 & 4 & 6 & 3 & 4 \\
\cline { 2 - 12 } & GR & {$[0.5,1.5]$} & {$[4.5,5.5]$} & {$[1.5,2.5]$} & {$[2.5,3.5]$} & {$[4.5,5.5]$} & {$[3.5,4.5]$} & {$[5.5,6.5]$} & {$[2.5,3.5]$} & {$[3.5,4.5]$} \\
\hline \multirow{2}{*}{ E5 } & CR & 1 & 5 & 1 or 2 & 3 & 6 & 4 & 3 & 2 or 3 & 5 \\
\cline { 2 - 12 } & GR & {$[0.5,1.5]$} & {$[4.5,5.5]$} & {$[0.5,2.5]$} & {$[2.5,3.5]$} & {$[5.5,6.5]$} & {$[3.5,4.5]$} & {$[2.5,3.5]$} & {$[1.5,3.5]$} & {$[4.5,5.5]$} \\
\hline \multirow{2}{*}{ E6 } & CR & 1 & 2 & 1 & 1 & 2 & 1 & 2 & 1 & 1 \\
\cline { 2 - 12 } & GR & {$[0.5,1.5]$} & {$[2.5,3.5]$} & {$[0.5,1.5]$} & {$[0.5,1.5]$} & {$[2.5,3.5]$} & {$[0.5,1.5]$} & {$[2.5,3.5]$} & {$[0.5,1.5]$} & {$[0.5,1.5]$} \\
\hline \multirow{2}{*}{ E7 } & CR & 1 & 6 & 3 & 5 & 7 & 4 & 8 & 2 & 9 \\
\cline { 2 - 12 } & GR & {$[0.5,1.5]$} & {$[5.5,6.5]$} & {$[2.5,3.5]$} & {$[4.5,5.5]$} & {$[6.5,7.5]$} & {$[3.5,4.5]$} & {$[7.5,8.5]$} & {$[2.5,3.5]$} & {$[8.5,9.5]$} \\
\hline \multirow{2}{*}{ E8 } & CR & 1 & 4 & 2 & 3 & 4 & 3 & 5 & 2 & 5 \\
\cline { 2 - 11 } & GR & {$[0.5,1.5]$} & {$[3.5,4.5]$} & {$[2.5,3.5]$} & {$[2.5,3.5]$} & {$[3.5,4.5]$} & {$[2.5,3.5]$} & {$[4.5,5.5]$} & {$[2.5,3.5]$} & {$[4.5,5.5]$} \\
\hline \multirow{2}{*}{ E9 } & CR & 1 & 5 & 2 & 3 & 5 & 4 & 5 & 6 & 7 \\
\cline { 2 - 11 } & GR & {$[0.5,1.5]$} & {$[4.5,5.5]$} & {$[2.5,3.5]$} & {$[2.5,3.5]$} & {$[4.5,5.5]$} & {$[3.5,4.5]$} & {$[4.5,5.5]$} & {$[5.5,6.5]$} & {$[6.5,7.5]$} \\
\hline \multirow{2}{*}{ E10 } & CR & 2 & 4 & 3 & 1 & 4 & 3 & 5 & 1 & 4 \\
\cline { 2 - 10 } & GR & {$[2.5,3.5]$} & {$[3.5,4.5]$} & {$[2.5,3.5]$} & {$[0.5,1.5]$} & {$[3.5,4.5]$} & {$[2.5,3.5]$} & {$[4.5,5.5]$} & {$[0.5,1.5]$} & {$[3.5,4.5]$} \\
\hline
\end{tabular}


Agricultural activity is the lifeline for human civilization. However, it is also a source of some adverse effects environment which are usually overlooked. Identifying and selecting appropriate low-carbon and sustainable technologies for the agriculture sector can reduce these adverse effects. Thus the current study identified the best low-carbon and sustainable agricultural technologies and then applied OPA-G methods to evaluate those technologies. After analyzing all experts' opinions, results show that all these technologies have some potential to be used in the agriculture sector to handle global climate change agricultural sustainability issues with varying degrees of priority. The current study finds that among all the available alternatives, integrated crop-livestock systems (ICLS), T1, constitute the best technology that can enhance food production and contribute to sustainable development while improving environmental quality by reducing net GHG emissions. The literature from different regions supports this finding. For example, Vinholis et al. (2021) showed that Brazil has already taken the initiative to adapt ICLS to its agriculture sector as a voluntary target of reducing emissions. By 2020 Brazil has adopted about 4 million hectares of land under ICLS and avoided 22.11 million tons of carbon dioxide (MAPA, 2019). In North America, Russelle et al. (2007) suggested that farmers should adapt ICLS technology to enhance firms' profitability and environmental sustainability. However, from Table 4, one can easily see the ranking of all available technologies. Figure 4 shows complete ranking.

In terms of sustainability criteria, results suggest all these technology has some viable potentiality to be used in the agricultural sector and the literature also suggests the same. But the current study did not find any literature that has suggested ranking for low carbon and sustainable agricultural technology under uncertainty. Therefore, the current study employed the OPA-G model to handle the uncertainty related to the agricultural sector and find the ranking among different alternatives. With the aid of the OPA-G method, decision-makers can genuinely enjoy a high level of flexibility in dealing with various sustainable criteria and uncertainty. Moreover, the OPA-G method does not require data normalization, a pairwise comparison matrix, and aggregating experts' opinions.

Table 6. Opinion of experts for the technologies against Social criteria

\begin{tabular}{|c|c|c|c|c|c|c|c|c|c|c|}
\hline Experts & $\begin{array}{l}\text { Rank } \\
\text { Type }\end{array}$ & T1 & T2 & T3 & T4 & T5 & T6 & T7 & T8 & T9 \\
\hline \multirow[t]{2}{*}{ E1 } & CR & 3 & 1 & 2 & 1 & 2 & 2 & 1 & 2 & 1 \\
\hline & GR & {$[2.5,3.5]$} & {$[0.5,1.5]$} & {$[1.5,2.5]$} & {$[0.5,1.5]$} & {$[1.5,2.5]$} & {$[1.5,2.5]$} & {$[0.5,1.5]$} & {$[1.5,2.5]$} & {$[0.5,1.5]$} \\
\hline \multirow[t]{2}{*}{ E2 } & $\begin{array}{l}\mathrm{CR} \\
\end{array}$ & 1 & 4 & 5 & 3 & 4 & 3 & 2 & 2 & 3 \\
\hline & GR & {$[0.5,1.5]$} & {$[3.5,4.5]$} & {$[4.5,5.5]$} & {$[2.5,3.5]$} & {$[3.5,4.5]$} & {$[2.5,3.5]$} & {$[1.5,2.5]$} & {$[1.5,2.5]$} & {$[2.5,3.5]$} \\
\hline \multirow[t]{2}{*}{ E3 } & CR & 2 & 3 & 4 & 2 & 3 & 1 & 4 & 4 & 5 \\
\hline & GR & {$[1.5,2.5]$} & {$[2.5,3.5]$} & {$[3.5,4.5]$} & {$[1.5,2.5]$} & {$[2.5,3.5]$} & {$[0.5,1.5]$} & {$[3.5,4.5]$} & {$[3.5,4.5]$} & {$[4.5,5.5]$} \\
\hline \multirow[t]{2}{*}{ E4 } & CR & 2 & 3 & 1 & 2 & 4 & 1 & 2 or 3 & 2 & 5 \\
\hline & GR & {$[1.5,2.5]$} & {$[3.5,4.5]$} & {$[0.5,1.5]$} & {$[1.5,2.5]$} & {$[3.5,4.5]$} & {$[0.5,1.5]$} & {$[1.5,3.5]$} & {$[1.5,2.5]$} & {$[4.5,5.5]$} \\
\hline \multirow[t]{2}{*}{ E5 } & CR & 2 & 3 & 1 & 4 & 3 & 5 & 3 & 2 & 3 \\
\hline & GR & {$[1.5,2.5]$} & {$[3.5,4.5]$} & {$[0.5,1.5]$} & {$[3.5,4.5]$} & {$[3.5,4.5]$} & {$[4.5,5.5]$} & {$[3.5,4.5]$} & {$[1.5,2.5]$} & {$[3.5,4.5]$} \\
\hline \multirow[t]{2}{*}{ E6 } & CR & 1 & 2 & 1 & 1 & 2 & 3 & 1 & 2 & 1 \\
\hline & GR & {$[0.5,1.5]$} & {$[1.5,2.5]$} & {$[0.5,1.5]$} & {$[0.5,1.5]$} & {$[1.5,2.5]$} & {$[3.5,4.5]$} & {$[0.5,1.5]$} & {$[1.5,2.5]$} & {$[0.5,1.5]$} \\
\hline \multirow[t]{2}{*}{ E7 } & CR & 5 & 8 & 4 & 6 & 2 & 1 & 9 & 3 & 7 \\
\hline & GR & {$[4.5,5.5]$} & {$[7.5,8.5]$} & {$[3.5,4.5]$} & {$[5.5,6.5]$} & {$[1.5,2.5]$} & {$[0.5,1.5]$} & {$[8.5,9.5]$} & {$[3.5,4.5]$} & {$[6.5,7.5]$} \\
\hline \multirow[t]{2}{*}{ E8 } & $\mathrm{CR}$ & 5 & 3 & 4 & 4 & 3 & 2 & 1 & 3 & 4 \\
\hline & GR & {$[4.5,5.5]$} & {$[3.5,4.5]$} & {$[3.5,4.5]$} & {$[3.5,4.5]$} & {$[3.5,4.5]$} & {$[1.5,2.5]$} & {$[0.5,1.5]$} & {$[3.5,4.5]$} & {$[3.5,4.5]$} \\
\hline \multirow[t]{2}{*}{ E9 } & CR & 4 & 2 & 3 & 4 & 2 & 5 & 5 & 4 & 2 \\
\hline & GR & {$[3.5,4.5]$} & {$[1.5,2.5]$} & {$[3.5,4.5]$} & {$[3.5,4.5]$} & {$[1.5,2.5]$} & {$[4.5,5.5]$} & {$[4.5,5.5]$} & {$[3.5,4.5]$} & {$[1.5,2.5]$} \\
\hline \multirow[t]{2}{*}{ E10 } & CR & 3 & 4 & 4 & 5 & 5 & 3 & 1 & 3 & 5 \\
\hline & GR & {$[3.5,4.5]$} & {$[3.5,4.5]$} & {$[3.5,4.5]$} & {$[4.5,5.5]$} & {$[4.5,5.5]$} & {$[3.5,4.5]$} & {$[0.5,1.5]$} & {$[3.5,4.5]$} & {$[4.5,5.5]$} \\
\hline
\end{tabular}


Table 7. Opinion of experts for the technologies against Environmental criteria

\begin{tabular}{|c|c|c|c|c|c|c|c|c|c|c|}
\hline Experts & $\begin{array}{l}\text { Rank } \\
\text { Type }\end{array}$ & T1 & $T 2$ & T3 & T4 & T5 & T6 & $T 7$ & T8 & T9 \\
\hline \multirow[t]{2}{*}{ E1 } & CR & 3 & 1 & 1 & 1 & 2 & 1 & 1 & 2 & 1 \\
\hline & GR & {$[2.5,3.5]$} & {$[0.5,1.5]$} & {$[0.5,1.5]$} & {$[0.5,1.5]$} & {$[1.5,2.5]$} & {$[0.5,1.5]$} & {$[0.5,1.5]$} & {$[1.5,2.5]$} & {$[0.5,1.5]$} \\
\hline \multirow[t]{2}{*}{ E2 } & CR & 3 & 2 & 5 & 4 & 2 & 1 & 1 & 5 & 4 or 5 \\
\hline & GR & {$[2.5,3.5]$} & {$[1.5,2.5]$} & {$[4.5,5.5]$} & {$[3.5,4.5]$} & {$[1.5,2.5]$} & {$[0.5,1.5]$} & {$[0.5,1.5]$} & {$[4.5,5.5]$} & {$[3.5,5.5]$} \\
\hline \multirow[t]{2}{*}{ E3 } & $\mathrm{CR}$ & 3 & 2 & 4 & 3 & 2 & 3 & 1 & 5 & 4 \\
\hline & GR & {$[2.5,3.5]$} & {$[1.5,2.5]$} & {$[3.5,4.5]$} & {$[2.5,3.5]$} & {$[1.5,2.5]$} & {$[2.5,3.5]$} & {$[0.5,1.5]$} & {$[4.5,5.5]$} & {$[3.5,4.5]$} \\
\hline \multirow[t]{2}{*}{$\mathrm{E} 4$} & CR & 3 & 1 & 4 & 2 & 4 & 3 & 1 & 4 & 3 \\
\hline & GR & {$[2.5,3.5]$} & {$[0.5,1.5]$} & {$[3.5,4.5]$} & {$[1.5,2.5]$} & {$[3.5,4.5]$} & {$[2.5,3.5]$} & {$[0.5,1.5]$} & {$[3.5,4.5]$} & {$[2.5,3.5]$} \\
\hline \multirow[t]{2}{*}{ E5 } & CR & 2 & 1 & 3 & 3 & 2 & 3 & 1 & 4 & 3 or 4 \\
\hline & GR & {$[1.5,2.5]$} & {$[0.5,1.5]$} & {$[2.5,3.5]$} & {$[2.5,3.5]$} & {$[1.5,2.5]$} & {$[2.5,3.5]$} & {$[0.5,1.5]$} & {$[3.5,4.5]$} & {$[2.5,4.5]$} \\
\hline \multirow[t]{2}{*}{ E6 } & CR & 2 & 2 & 3 & 1 & 2 & 2 & 1 & 3 & 2 \\
\hline & GR & {$[1.5,2.5]$} & {$[1.5,2.5]$} & {$[2.5,3.5]$} & {$[0.5,1.5]$} & {$[1.5,2.5]$} & {$[1.5,2.5]$} & {$[0.5,1.5]$} & {$[2.5,3.5]$} & {$[1.5,2.5]$} \\
\hline \multirow[t]{2}{*}{ E7 } & $\mathrm{CR}$ & 9 & 3 & 7 & 6 & 5 & 4 & 1 & 8 & 2 \\
\hline & GR & {$[8.5,9.5]$} & {$[2.5,3.5]$} & {$[6.5,7.5]$} & {$[5.5,6.5]$} & {$[4.5,5.5]$} & {$[3.5,4.5]$} & {$[0.5,1.5]$} & {$[7.5,8.5]$} & {$[1.5,2.5]$} \\
\hline \multirow[t]{2}{*}{ E8 } & CR & 3 & 1 & 3 & 2 & 4 & 2 & 1 & 4 & 3 \\
\hline & GR & {$[3.5,4.5]$} & {$[0.5,1.5]$} & {$[3.5,4.5]$} & {$[1.5,2.5]$} & {$[3.5,4.5]$} & {$[1.5,2.5]$} & {$[0.5,1.5]$} & {$[3.5,4.5]$} & {$[3.5,4.5]$} \\
\hline \multirow[t]{2}{*}{ E9 } & CR & 2 & 1 & 3 & 4 & 3 & 3 & 1 & 4 & 5 \\
\hline & GR & {$[1.5,2.5]$} & {$[0.5,1.5]$} & {$[3.5,4.5]$} & {$[3.5,4.5]$} & {$[3.5,4.5]$} & {$[3.5,4.5]$} & {$[0.5,1.5]$} & {$[3.5,4.5]$} & {$[4.5,5.5]$} \\
\hline \multirow[t]{2}{*}{ E10 } & $\mathrm{CR}$ & 4 & 1 & 5 & 4 & 3 & 3 & 1 & 3 & 2 \\
\hline & GR & {$[3.5,4.5]$} & {$[0.5,1.5]$} & {$[4.5,5.5]$} & {$[3.5,4.5]$} & {$[3.5,4.5]$} & {$[3.5,4.5]$} & {$[0.5,1.5]$} & {$[3.5,4.5]$} & {$[1.5,2.5]$} \\
\hline
\end{tabular}

Table 8. Weights and ranking of criteria

\begin{tabular}{|c|c|c|c|c|}
\hline Criteria & Lower limit & Upper limit & Average weights & Rank \\
\hline Economy & 0.2792 & 0.4557 & 0.3674 & 2 \\
\hline Social & 0.1820 & 0.2232 & 0.2026 & 3 \\
\hline Environmental & 0.3388 & 0.5211 & 0.4300 & 1 \\
\hline
\end{tabular}

\section{Conclusion and recommendations}

Climate change is a global issue, and the agricultural sector is an integral part of it. Agriculture activities significantly influence the economy, society, and environment, which are the main indicator of sustainable development. Using low-carbon and sustainable agricultural technology can help mitigate the adverse effect on the environment and increase global food security. But selecting appropriate lowcarbon and sustainable agricultural technology for the agricultural industry becomes a big problem. There are many MCDM methods in literature to help decision-makers, but several methods are not equipped to deal with uncertainty in information. Thus, this study employed the Grey Ordinal Priority Approach (OPA-G), a modern multi-attribute decision-making technique that will help decision-makers select the best possible alternatives/technologies for the agricultural industry.

To achieve sustainable development goals (SDGs), the contribution of the agriculture sector cannot be neglected. Implications of low-carbon and sustainable agricultural technology is an inevitable choice for government and policymakers in developed and developing countries. Despite the negative effects from the agriculture sector, it would be easier to mitigate climate change than any other sector. This study identified a number of well-known key low-carbon and sustainable agricultural technologies that have proven their usefulness for all agriculture activities in most countries and have the potential to be used. The implications of these technologies in the agriculture sector can help tackle global climate change and ensure global food security. 
Table 9. Weights and ranking of technologies

\begin{tabular}{|c|c|c|c|c|}
\hline Alternatives & Lower limit & Upper limit & Average weights & Rank \\
\hline Integrated crop-livestock systems (T1) & 0.1313 & 0.2100 & 0.1706 & 1 \\
\hline No-tillage (T2) & 0.0979 & 0.1877 & 0.1428 & 2 \\
\hline Integrated crop-livestock-forest system (T3) & 0.0971 & 0.1342 & 0.1156 & 5 \\
\hline Conservation agriculture (T4) & 0.1007 & 0.1614 & 0.1310 & 4 \\
\hline Integrated Soil Fertility Management (T5) & 0.0600 & 0.0808 & 0.0704 & 7 \\
\hline Agroforestry (T6) & 0.0932 & 0.1157 & 0.1045 & 6 \\
\hline Carbon sequestration (T7) & 0.1097 & 0.1596 & 0.1346 & 3 \\
\hline Crop diversification (T8) & 0.0602 & 0.0788 & 0.0695 & 8 \\
\hline Soil and water conservation (T9) & 0.0499 & 0.0720 & 0.0609 & 9 \\
\hline
\end{tabular}

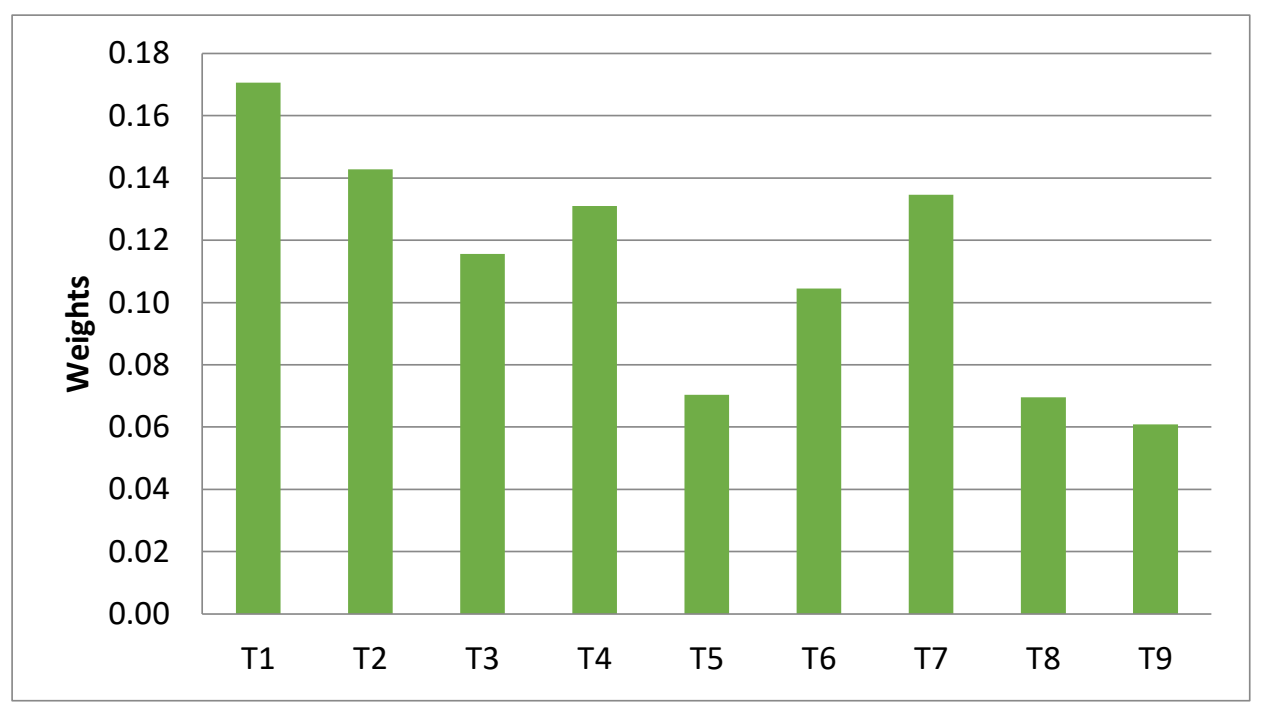

Figure 4. The ranking of technologies based on the OPA-G

Although the theory of the OPA-G model seems superior in many aspects when compared with the classical MCDM theories, it can further be improved. Identifying qualified experts for the data collection of different alternatives based on a sustainable approach has brought more research questions for this model. Experts' opinions are crucial for the decision-making process; experts' unfair or biased judgment can affect the final results. A standardized objective methodology to prioritize experts is needed. The development of a tool to predict the level of reliability can improve its effectiveness. The model should be applied to solve diverse problems to better understand its limitations and strengths in the future.

\section{Acknowledgements}

The work is a derivate of the author's undergraduate thesis submitted to the Nanjing University of Information Science and Technology, Nanjing, P. R. China.

\section{References}

Abdalla, K., Chivenge, P., Ciais, P., \& Chaplot, V. (2016). No-tillage lessens soil $\mathrm{CO}_{2}$ emissions the most under arid and sandy soil conditions: results from a meta-analysis. Biogeosciences, 13(12), 3619-3633. https://doi.org/10.5194/bg-13-3619-2016

Abid, N., Ikram, M., Wu, J., \& Ferasso, M. (2021). Towards environmental sustainability: Exploring the nexus among ISO 14001, governance indicators and green economy in Pakistan. Sustainable Production and Consumption, 27, 653-666. https://doi.org/10.1016/j.spc.2021.01.024 
Adimassu, Z., Langan, S., Johnston, R., Mekuria, W., \& Amede, T. (2017). Impacts of soil and water conservation practices on crop yield, run-off, soil loss and nutrient loss in Ethiopia: review and synthesis. Environmental Management, 59(1), 87-101. https://doi.org/10.1007/s00267-016-0776-1

Amadu, F. O., Miller, D. C., \& McNamara, P. E. (2020). Agroforestry as a pathway to agricultural yield impacts in climate-smart agriculture investments: Evidence from southern Malawi. Ecological Economics, 167, 106443. https://doi.org/10.1016/j.ecolecon.2019.106443

Amindoust, A. (2018). A resilient-sustainable based supplier selection model using a hybrid intelligent method. Computers \& Industrial Engineering, 126, 122-135. https://doi.org/10.1016/j.cie.2018.09.031

An, D., Xi, B., Ren, J., Ren, X., Zhang, W., Wang, Y., \& Dong, L. (2018). Multi-criteria sustainability assessment of urban sludge treatment technologies: Method and case study. Resources, Conservation and Recycling, 128, 546554. https://doi.org/10.1016/j.resconrec.2016.08.018

Anuga, S. W., Chirinda, N., Nukpezah, D., Ahenkan, A., Andrieu, N., \& Gordon, C. (2020). Towards low carbon agriculture: Systematic-narratives of climate-smart agriculture mitigation potential in Africa. Current Research in Environmental Sustainability, 2, 100015. http:/ /dx.doi.org/10.1016/j.crsust.2020.100015

Arcipowska, A. Mangan, E. Lyu, Y. Wate, R. (2019, July 29). 5 Questions About Agricultural Emissions, Answered. World Resources Institute. Retrieved from https://www.wri.org/blog/2019/07/5-questions-aboutagricultural-emissions-answered.

Asfaw, D., \& Neka, M. (2017). Factors affecting adoption of soil and water conservation practices: the case of Wereillu Woreda (District), South Wollo Zone, Amhara Region, Ethiopia. International Soil and Water Conservation Research, 5(4), 273-279. https://doi.org/10.1016/j.iswcr.2017.10.002

Ataei, Y., Mahmoudi, A., Feylizadeh, M. R., \& Li, D. F. (2020). Ordinal priority approach (OPA) in multiple attributedecisionmaking. Applied Soft Computing, 86, 105893. https://doi.org/10.1016/j.asoc.2019.105893

Awasthi, A., Govindan, K., \& Gold, S. (2018). Multi-tier sustainable global supplier selection using a fuzzy AHPVIKOR based approach. International Journal of Production Economics, 195, 106-117. https://doi.org/10.1016/j.ijpe.2017.10.013

Aydemir, E., \& Sahin, Y. (2019). Evaluation of healthcare service quality factors using grey relational analysis in a dialysis center. Grey Systems: Theory and Application, 9(4), 432-448.

Beach, R. H., DeAngelo, B. J., Rose, S., Li, C., Salas, W., \& DelGrosso, S. J. (2008). Mitigation potential and costs for global agricultural greenhouse gas emissions 1. Agricultural Economics, 38(2), 109-115. https://doi.org/10.1111/j.1574-0862.2008.00286.x

Bennetzen, E. H., Smith, P., \& Porter, J. R. (2016). Decoupling of greenhouse gas emissions from global agricultural production: 1970-2050. Global Change Biology, 22(2), 763-781. https://doi.org/10.1111/gcb.13120

Bhatia, A., Jain, N., \& Pathak, H. (2012). Greenhouse gas emissions from Indian agriculture. Low Carbon Technologies for Agriculture: A Study on Rice and Wheat Systems in the Indo-Gangetic Plains (Pathak H, Aggarwal PK, eds.). New Delhi, India: Indian Agricultural Research Institute.

Birthal, P. S., \& Hazrana, J. (2019). Crop diversification and resilience of agriculture to climatic shocks: Evidence from India. Agricultural Systems, 173, 345-354. https://doi.org/10.1016/j.agsy.2019.03.005

Cardoen, D., Joshi, P., Diels, L., Sarma, P. M., \& Pant, D. (2015). Agriculture biomass in India: Part 2. Post-harvest losses, cost and environmental impacts. Resources, Conservation and Recycling, 101, 143-153. http://dx.doi.org/10.1016/j.resconrec.2015.06.002

Chen, H.-B., Pei, L.-L., \& Zhao, Y.-F. (2021). Forecasting seasonal variations in electricity consumption and electricity usage efficiency of industrial sectors using a grey modeling approach. Energy, 222, 119952. https://doi.org/10.1016/j.energy.2021.119952

Chithambaranathan, P., Subramanian, N., Gunasekaran, A., \& Palaniappan, P. K. (2015). Service supply chain environmental performance evaluation using grey based hybrid MCDM approach. International Journal of Production Economics, 166, 163-176. https://doi.org/ 10.1016/j.ijpe.2015.01.002

de Moraes Sá, J. C., Lal, R., Cerri, C. C., Lorenz, K., Hungria, M., \& de Faccio Carvalho, P. C. (2017). Low-carbon agriculture in South America to mitigate global climate change and advance food security. Environment International, 98, 102-112. http://dx.doi.org/10.1016/j.envint.2016.10.020

De Stefano, A., \& Jacobson, M. G. (2018). Soil carbon sequestration in agroforestry systems: a meta-analysis. Agroforestry Systems, 92(2), 285-299. https://doi.org/10.1007/s10457-017-0147-9

Deshavath, N. N., Veeranki, V. D., \& Goud, V. V. (2019). Lignocellulosic feedstocks for the production of bioethanol: availability, structure, and composition. In Sustainable Bioenergy (pp. 1-19). Elsevier. https://doi.org/10.1016/B978-0-12-817654-2.00001-0

Dimassi, B., Cohan, J. P., Labreuche, J., \& Mary, B. (2013). Changes in soil carbon and nitrogen following tillage conversion in a long-term experiment in Northern France. Agriculture, Ecosystems \& Environment, 169, 12-20. https://doi.org/10.1016/j.agee.2013.01.012 
EU. (2018). Archive: Agriculture - greenhouse gas emission statistics. Eurostat. Retrieved from https:/ /ec.europa.eu/eurostat/statistics-explained/index.php?title=Archive:Agriculture__greenhouse_gas_emission_statistics\&oldid=273928 (Accessed on 25 Nov 2020).

FAO. (2020). Sustainable Development Goals. Food and Agriculture Organization of the United Nations. Retrieved from http://www.fao.org/sustainable-development-goals/goals/goal-2/en/ (Accessed on 15 Feb 2021)

FAO. (2021). Sustainable Food and Agriculture. Retrieved from http://www.fao.org/sustainability/en/ (Accessed on 23 Feb 2021)

Field, C. B., Barros, V., Stocker, T., Qin, D., Dokken, D., Ebi, K., ... \& Midgley, P. (2012). Managing the risks of extreme events and disasters to advance climate change adaptation. A special report of Working Groups I and II of the Intergovernmental Panel on Climate Change. Cambridge University Press, Cambridge, UK, and New York, NY, USA.

Gerber, P., Vellinga, T., Opio, C., \& Steinfeld, H. (2011). Productivity gains and greenhouse gas emissions intensity in dairy systems. Livestock Science, 139(1-2), 100-108. https://doi.org/10.1016/j.livsci.2011.03.012

Ghadimi, P., Toosi, F. G., \& Heavey, C. (2018). A multi-agent systems approach for sustainable supplier selection and order allocation in a partnership supply chain. European Journal of Operational Research, 269(1), 286-301. https://doi.org/10.1016/j.ejor.2017.07.014

Gilbert, N. (2012). Dirt poor: the key to tackling hunger in Africa is enriching its soil. The big debate is about how to do it. Nature, 483(7391), 525-528.

Hao, Y., Yeh, T. C. J., Gao, Z., Wang, Y., \& Zhao, Y. (2006). A gray system model for studying the response to climatic change: The Liulin karst springs, China. Journal of Hydrology, 328(3-4), 668-676. https://doi.org/10.1016/j.jhydrol.2006.01.022

Hatfield, J., Takle, E., Grotjahn, R., Holden, P., Izaurralde, R. C., Mader, T., ... \& Liverman, D. (2014). Agriculture. Climate Change Impacts in the United States: The Third National Climate Assessment. https://doi.org/10.7930/J02Z13FR.

Hendrickson, J. R., Hanson, J. D., Tanaka, D. L., \& Sassenrath, G. (2008). Principles of integrated agricultural systems: Introduction to processes and definition. Renewable Agriculture and Food Systems, 23(4), 265-271. https://doi.org/10.1017/S1742170507001718

Hobbs, P. R., Sayre, K., \& Gupta, R. (2008). The role of conservation agriculture in sustainable agriculture. Philosophical Transactions of the Royal Society B: Biological Sciences, 363(1491), 543-555. https://doi.org/10.1098/rstb.2007.2169

Hou, J., \& Hou, B. (2019). Farmers' adoption of low-carbon agriculture in China: An extended theory of the planned behavior model. Sustainability, 11(5), 1399. https://doi.org/10.3390/su11051399

Huang, C.-Y., Hsu, C.-C., Chiou, M.-L., \& Chen, C.-I. (2020). The main factors affecting Taiwan's economic growth rate via dynamic grey relational analysis. PLOS ONE, 15(10), e0240065. https://doi.org/10.1371/journal.pone.0240065

Ikram, M., Zhang, Q., Sroufe, R., \& Ferasso, M. (2021). Contribution of Certification Bodies and Sustainability Standards to Sustainable Development Goals: An Integrated Grey Systems Approach. Sustainable Production and Consumption, 28, 326-345. https://doi.org/10.1016/j.spc.2021.05.019

Javed, S. A., \& Liu, S. (2018). Evaluation of outpatient satisfaction and service quality of Pakistani healthcare projects. Grey Systems: Theory and Application, 8(4), 462-480. https://doi.org/10.1108/GS-04-2018-0018

Javed, S. A., Mahmoudi, A., \& Liu, S. (2020). Grey Absolute Decision Analysis (GADA) Method for Multiple Criteria Group Decision-Making Under Uncertainty. International Journal of Fur:y Systems, 22(4), 1073-1090. https://doi.org/10.1007/s40815-020-00827-8

Javed, S.A., \& Liu, S. (2019). Bidirectional Absolute GRA/GIA model for Uncertain Systems: Application in Project Management. IEEE Access, 7(1), 60885-60896. https://doi.org/10.1109/ACCESS.2019.2904632

Jobbágy, E. G., \& Jackson, R. B. (2000). The vertical distribution of soil organic carbon and its relation to climate and vegetation. Ecological Applications, 10(2), 423-436. https://doi.org/10.2307/2641104

Ju-Long, D. (1982). Control problems of grey systems. Systems \& Control Letters, 1(5), 288-294. https://doi.org/10.1016/S0167-6911(82)80025-X

Kassam, A., Friedrich, T., Shaxson, F., \& Pretty, J. (2009). The spread of conservation agriculture: justification, sustainability and uptake. International Journal of Agricultural Sustainability, 7(4), 292-320. https://doi.org/10.3763/ijas.2009.0477

Kassie, M., Köhlin, G., Bluffstone, R., \& Holden, S. (2011, May). Are soil conservation technologies "win-win?" A case study of Anjeni in the north-western Ethiopian highlands. In natural resources forum (Vol. 35, No. 2, pp. 89-99). Oxford, UK: Blackwell Publishing Ltd. https://doi.org/10.1111/j.1477-8947.2011.01379.x

Kato, E., Ringler, C., Yesuf, M., \& Bryan, E. (2011). Soil and water conservation technologies: a buffer against production risk in the face of climate change? Insights from the Nile basin in Ethiopia. Agricultural Economics, 42(5), 593-604. https://doi.org/10.1111/j.1574-0862.2011.00539.x

Khan, R. (2020). Agricultural production and CO2 emissions causes in the developing and developed countries: New insights from quantile regression and decomposition analysis. bioRxiv. https://doi.org/10.1101/2020.11.16.384370 
Kumar, P., \& Singh, R. K. (2021). Selection of sustainable solutions for crop residue burning: an environmental issue in northwestern states of India. Environment, Development and Sustainability, 23(3), 3696-3730. https://doi.org/10.1007/s10668-020-00741-x

Lambrecht, I., Vanlauwe, B., \& Maertens, M. (2016). Integrated soil fertility management: from concept to practice in Eastern DR Congo. International Journal of Agricultural Sustainability, 14(1), 100-118. https://doi.org/10.1080/14735903.2015.1026047

Li, J., Fang, H., \& Song, W. (2019). Sustainable supplier selection based on SSCM practices: A rough cloud TOPSIS approach. Journal of Cleaner Production, 222, 606-621. https://doi.org/10.1016/j.jclepro.2019.03.070

Li, W., Ruiz-Menjivar, J., Zhang, L., \& Zhang, J. (2021). Climate change perceptions and the adoption of lowcarbon agricultural technologies: Evidence from rice production systems in the Yangtze River Basin. Science of The Total Environment, 759, 143554. https://doi.org/10.1016/j.scitotenv.2020.143554

Lithourgidis, A. S., Dordas, C. A., Damalas, C. A., \& Vlachostergios, D. (2011). Annual intercrops: an alternative pathway for sustainable agriculture. Australian Journal of Crop Science, 5(4), 396-410. https://search.informit.org/doi/10.3316/informit.281409060336481

Luo, Z., Wang, E., \& Sun, O. J. (2010). Can no-tillage stimulate carbon sequestration in agricultural soils? A metaanalysis of paired experiments. Agriculture, Ecosystems \& Environment, 139(1-2), 224-231. https://doi.org/10.1016/j.agee.2010.08.006

Lybbert, T. J., \& Sumner, D. A. (2012). Agricultural technologies for climate change in developing countries: Policy options for innovation and technology diffusion. Food Policy, 37(1), 114-123. DOI: 10.1016/j.foodpol.2011.11.001

Ma, X. (2019). A Brief Introduction to the Grey Machine Learning. The Journal of Grey System, 31(1), 1-12.

Magrini, M. B., Anton, M., Cholez, C., Corre-Hellou, G., Duc, G., Jeuffroy, M. H., ... \& Walrand, S. (2016). Why are grain-legumes rarely present in cropping systems despite their environmental and nutritional benefits? Analyzing lock-in in the French agrifood system. Ecological Economics, 126, 152-162. https://doi.org/10.1016/j.ecolecon.2016.03.024

Mahmoudi, A., Deng, X., Javed, S. A., \& Yuan, J. (2020a). Large-scale multiple criteria decision-making with missing values: project selection through TOPSIS-OPA. Journal of Ambient Intelligence and Humanized Computing, 1-22. https://doi.org/10.1007/s12652-020-02649-w

Mahmoudi, A., Deng, X., Javed, S. A., \& Zhang, N. (2021a). Sustainable supplier selection in megaprojects: Grey Ordinal Priority Approach. Business Strategy and the Environment, 30(1), 318-339. https://doi.org/10.1002/bse.2623

Mahmoudi, A., Javed, S. A., \& Mardani, A. (2021b). Gresilient Supplier Selection through Fuzzy Ordinal Priority Approach: Decision-making in Post-COVID era. Operations Management Research. DOI:10.1007/s12063-02100178-Z

Mahmoudi, A., Javed, S. A., Liu, S., \& Deng, X. (2020b). Distinguishing coefficient driven sensitivity analysis of GRA model for intelligent decisions: application in project management. Technological and Economic Development of Economy, 26(3), 621-641. DOI: https://doi.org/10.3846/tede.2020.11890

MAPA. (2020). Ministry of Agriculture, Livestock, and Food Supply. Plano ABC em Números. https://www.gov.br/agricultura/pt-br/assuntos/sustentabilidade/ plano-abc/plano-abc-em-numeros. (Accessed 10 Dec 2020)

Martin, D. A., Osen, K., Grass, I., Hölscher, D., Tscharntke, T., Wurz, A., \& Kreft, H. (2020). Land-use history determines ecosystem services and conservation value in tropical agroforestry. Conservation Letters, 13(5), e12740. https://doi.org/10.1111/conl.12740

Memari, A., Dargi, A., Jokar, M. R. A., Ahmad, R., \& Rahim, A. R. A. (2019). Sustainable supplier selection: A multi-criteria intuitionistic fuzzy TOPSIS method. Journal of Manufacturing Systems, 50, 9-24. https://doi.org/10.1016/j.jmsy.2018.11.002

Meynard, J. M., Charrier, F., Le Bail, M., Magrini, M. B., Charlier, A., \& Messéan, A. (2018). Socio-technical lockin hinders crop diversification in France. Agronomy for Sustainable Development, 38(5), 54. https://doi.org/10.1007/s13593-018-0535-1

Mo, D., Jiang, Q. Y., Li, D. Q., Chen, C. J., Zhang, B. M., \& Liu, J. W. (2017). Controlled-source electromagnetic data processing based on gray system theory and robust estimation. Applied Geophysics, 14(4), 570-580. https://doi.org/10.1007/s11770-017-0646-5

Moraine, M., Duru, M., Nicholas, P., Leterme, P., \& Therond, O. (2014). Farming system design for innovative crop-livestock integration in Europe. Animal, 8(8), 1204-1217. https://doi.org/10.1017/S1751731114001189

Mwalupaso, G. E., Korotoumou, M., Eshetie, A. M., Alavo, J. P. E., \& Tian, X. (2019). Recuperating dynamism in agriculture through adoption of sustainable agricultural technology-Implications for cleaner production. Journal of Cleaner Production, 232, 639-647. https://doi.org/10.1016/j.jclepro.2019.05.366

Nair, P. K. R., Mohan Kumar, B., \& Nair, V. D. (2009). Agroforestry as a strategy for carbon sequestration. Journal of Plant Nutrition and Soil Science, 172(1), 10-23. https://doi.org/10.1002/jpln.200800030 
Nair, P. K. R., Nair, V. D., Kumar, B. M., \& Showalter, J. M. (2010). Carbon sequestration in agroforestry systems. Advances in Agronomy, 108, 237-307. https://doi.org/10.1016/S0065-2113(10)08005-3

Olesen, J. E., Trnka, M., Kersebaum, K. C., Skjelvåg, A. O., Seguin, B., Peltonen-Sainio, P., ... \& Micale, F. (2011). Impacts and adaptation of European crop production systems to climate change. European Journal of Agronomy, 34(2), 96-112. https://doi.org/10.1016/j.eja.2010.11.003

Page, K. L., Dang, Y. P., Dalal, R. C., Reeves, S., Thomas, G., Wang, W., \& Thompson, J. P. (2019). Changes in soil water storage with no-tillage and crop residue retention on a Vertisol: Impact on productivity and profitability over a 50 year period. Soil and Tillage Research, 194, 104319. https://doi.org/10.1016/j.still.2019.104319

Pathak, H., Chakrabarti, B., \& Aggarwal, P. K. (2012). Promotion of low carbon technologies in Indian Agriculture: Opportunities and Constraints. Low Carbon Technologies for Agriculture: A Study on Rice and Wheat Systems in the Indo-Gangetic Plains. New Delhi, India: Indian Agricultural Research Institute.

Paustian, K., Lehmann, J., Ogle, S., Reay, D., Robertson, G. P., \& Smith, P. (2016). Climate-smart soils. Nature, 532(7597), 49-57. https://doi.org/10.1016/j.scitotenv.2020.139506

Powlson, D. S., Stirling, C. M., Jat, M. L., Gerard, B. G., Palm, C. A., Sanchez, P. A., \& Cassman, K. G. (2014). Limited potential of no-till agriculture for climate change mitigation. Nature Climate Change, 4(8), 678-683. https://doi.org/10.1038/nclimate2292

Powlson, D. S., Stirling, C. M., Thierfelder, C., White, R. P., \& Jat, M. L. (2016). Does conservation agriculture deliver climate change mitigation through soil carbon sequestration in tropical agro-ecosystems?. Agriculture, Ecosystems \& Environment, 220, 164-174. https://doi.org/10.1016/j.agee.2016.01.005

Prasad, S., Singh, A., Korres, N. E., Rathore, D., Sevda, S., \& Pant, D. (2020). Sustainable utilization of crop residues for energy generation: A life cycle assessment (LCA) perspective. Bioresource Technology, 303, 122964. https://doi.org/10.1016/j.biortech.2020.122964

Ray, D. K., Gerber, J. S., MacDonald, G. K., \& West, P. C. (2015). Climate variation explains a third of global crop yield variability. Nature Communications, 6(1), 1-9. https://doi.org/10.1038/ncomms6989

Rehman, A., Ma, H., Irfan, M., \& Ahmad, M. (2020). Does carbon dioxide, methane, nitrous oxide, and GHG emissions influence the agriculture? Evidence from China. Environmental Science and Pollution Research, 27(23), 28768-28779. https://doi.org/10.1007/s11356-020-08912-z

Ren, J., Liang, H., \& Chan, F. T. (2017). Urban sewage sludge, sustainability, and transition for Eco-City: Multicriteria sustainability assessment of technologies based on best-worst method. Technological Forecasting and Social Change, 116, 29-39. https://doi.org/10.1016/j.techfore.2016.10.070

Roobroeck, D., van Asten, P. J., Jama, B., Harawa, R., \& Vanlauwe, B. (2015). Integrated Soil Fertility Management: Contributions of framework and practices to climate-smart agriculture. Climate-Smart Agriculture Practice Brief. Copenhagen, Denmark: CGIAR Research Program on Climate Change, Agriculture and Food Security https://hdl.handle.net/20.500.12478/724

Russell, S. (2014). Everything You Need to Know About Agricultural Emissions. World Resources Institute. Retrieved from https://www.wri.org/insights/everything-you-need-know-about-agricultural-emissions

Russelle, M. P., Entz, M. H., \& Franzluebbers, A. J. (2007). Reconsidering integrated crop-livestock systems in North America. Agronomy Journal, 99(2), 325334. https://doi.org/10.2134/agronj2006.0139

Schlesinger, W. H. (1999). Carbon sequestration in soils. Science, 284(5423), 2095. DOI:10.1126/science.284.5423.2095.

Shajedul, I. (2021). Islam's Grey Ordinal Priority Approach Algorithm. Zenodo. Retrieved from https://doi.org/10.5281/zenodo.4674547

Sheikh, A. H. A., Ikram, M., Ahmad, R. M., Qadeer, H., \& Nawaz, M. (2019). Evaluation of key factors influencing process quality during construction projects in Pakistan. Grey Systems: Theory and Application, 9(3), 321-335. https://doi.org/10.1108/GS-01-2019-0002

Sikora, J., Niemiec, M., Szelag-Sikora, A., Gródek-Szostak, Z., Kuboń, M., \& Komorowska, M. (2020). The Impact of a Controlled-Release Fertilizer on Greenhouse Gas Emissions and the Efficiency of the Production of Chinese Cabbage. Energies, 13(8), 2063. https://doi.org/10.3390/en13082063

Singha, C., Swain, K. C., \& Swain, S. K. (2020). Best crop rotation selection with GIS-AHP technique using soil nutrient variability. Agriculture, 10(6), 213. https://doi.org/10.3390/agriculture10060213

Six, J., Bossuyt, H., Degryze, S., \& Denef, K. (2004). A history of research on the link between (micro) aggregates, soil biota, and soil organic matter dynamics. Soil and Tillage Research, 79(1), 7-31. https://doi.org/10.1016/j.still.2004.03.008

Smith, P., Clark, H., Dong, H., Elsiddig, E. A., Haberl, H., Harper, R., ... \& Tubiello, F. (2014). Agriculture, forestry and other land use (AFOLU). The Intergovernmental Panel on Climate Change. Retrieved from http://www.ipcc.ch/pdf/assessment-report/ar5/wg3/i

Tan, Q., Farquharson, B., Chen, D., \& Liu, J. (2014). An analysis of factors influencing the output value of unit sown area based on grey incidence analysis. Grey Systems: Theory and Application, 4(1), 56-71. https://doi.org/10.1108/GS-09-2012-0032 
Tian, Y., Zhang, J., \& Li, B. (2011). Research on spatial-temporal characteristics and factor decomposition of agricultural carbon emission based on input angle-taking Hubei Province for example. Research of Agricultural Modernization, 32(6), 752-755.

Tongwane, M. I., \& Moeletsi, M. E. (2018). A review of greenhouse gas emissions from the agriculture sector in Africa. Agricultural Systems, 166, 124-134. https://doi.org/10.1016/j.agsy.2018.08.011

Uppala, S., Chapala, M. M., Kumar, K. V. K., Pavuluri, K., \& Chandra, K. J. (2016). Climate Change, Carbon Offsets and Low Carbon Technologies in Agriculture: A Review. International Journal of Horticulture \& Agriculture, 2(1),1-8. https://doi.org/10.15226/2572-3154/2/1/00106

Ussiri, D. A., \& Lal, R. (2009). Long-term tillage effects on soil carbon storage and carbon dioxide emissions in continuous corn cropping system from an alfisol in Ohio. Soil and Tillage Research, 104(1), 39-47. https://doi.org/10.1016/j.still.2008.11.008

Valani, G. P., Martíni, A. F., da Silva, L. F. S., Bovi, R. C., \& Cooper, M. (2021). Soil quality assessments in integrated crop-livestock-forest systems: A review. Soil Use and Management, 37(1), 22-36. https://doi.org/10.1111/sum.12667

Valbuena, D., Erenstein, O., Tui, S. H. K., Abdoulaye, T., Claessens, L., Duncan, A. J., ... \& van Wijk, M. T. (2012). Conservation Agriculture in mixed crop-livestock systems: Scoping crop residue trade-offs in Sub-Saharan Africa and South Asia. Field Crops Research, 132, 175-184. https://doi.org/10.1016/j.fcr.2012.02.022

Vanlauwe, B., Descheemaeker, K., Giller, K. E., Huising, J., Merckx, R., Nziguheba, G., ... \& Zingore, S. (2015). Integrated soil fertility management in sub-Saharan Africa: unravelling local adaptation. Soil, 1(1), 491-508. https://doi.org/10.5194/soil-1-491-2015

Vetter, S. H., Sapkota, T. B., Hillier, J., Stirling, C. M., Macdiarmid, J. I., Aleksandrowicz, L., ... \& Smith, P. (2017). Greenhouse gas emissions from agricultural food production to supply Indian diets: Implications for climate change mitigation. Agriculture, Ecosystems \& Environment, 237, 234-241. https://doi.org/10.1016/j.agee.2016.12.024

Vinholis, M. D. M. B., Saes, M. S. M., Carrer, M. J., \& de Souza Filho, H. M. (2020). The effect of meso-institutions on adoption of sustainable agricultural technology: A case study of the Brazilian Low Carbon Agriculture Plan. Journal of Cleaner Production, 280, 124334. https://doi.org/10.1016/j.jclepro.2020.124334

Waldron, A., Garrity, D., Malhi, Y., Girardin, C., Miller, D. C., \& Seddon, N. (2017). Agroforestry can enhance food security while meeting other sustainable development goals. Tropical Conservation Science, 10, 1940082917720667. https://doi.org/10.1177/1940082917720667

Wang, B., Song, J., Ren, J., Li, K., \& Duan, H. (2019). Selecting sustainable energy conversion technologies for agricultural residues: A fuzzy AHP-VIKOR based prioritization from life cycle perspective. Resources, Conservation and Recycling, 142, 78-87. https://doi.org/10.1016/j.resconrec.2018.11.011

West, T. O., \& Marland, G. (2002). A synthesis of carbon sequestration, carbon emissions, and net carbon flux in agriculture: comparing tillage practices in the United States. Agriculture, Ecosystems \& Environment, 91(1-3), 217-232. https://doi.org/10.1016/S0167-8809(01)00233-X

Wheeler, T., \& Von Braun, J. (2013). Climate change impacts on global food security. Science, 341(6145), 508-513. https://doi.org/10.1126/science.1239402

Xiao, X., Duan, H., \& Wen, J. (2020). A novel car-following inertia gray model and its application in forecasting short-term traffic flow. Applied Mathematical Modelling, 87, 546-570. https://doi.org/10.1016/j.apm.2020.06.020

Xie, W, Wu, W., \& Liu, C. (2021). An unified framework, for fractional grey system models: Memory effects perspective. arXiv. https://arxiv.org/abs/2103.10809v1

Yaekob, T., Tamene, L., Gebrehiwot, S. G., Demissie, S. S., Adimassu, Z., Woldearegay, K., ... \& Thorne, P. (2020). Assessing the impacts of different land uses and soil and water conservation interventions on runoff and sediment yield at different scales in the central highlands of Ethiopia. Renewable Agriculture and Food Systems, 1-15. https://doi.org/10.1017/S1742170520000010.

Yu, C., Shao, Y., Wang, K., \& Zhang, L. (2019). A group decision making sustainable supplier selection approach using extended TOPSIS under interval-valued Pythagorean fuzzy environment. Expert Systems with Applications, 121, 1-17. https://doi.org/10.1016/j.eswa.2018.12.010

Zhu, B., Yuan, L., \& Ye, S. (2019). Examining the multi-timescales of European carbon market with grey relational analysis and empirical mode decomposition. Physica A-Statistical Mechanics and Its Applications, 517, 392-399. https://doi.org/10.1016/j.physa.2018.11.016 